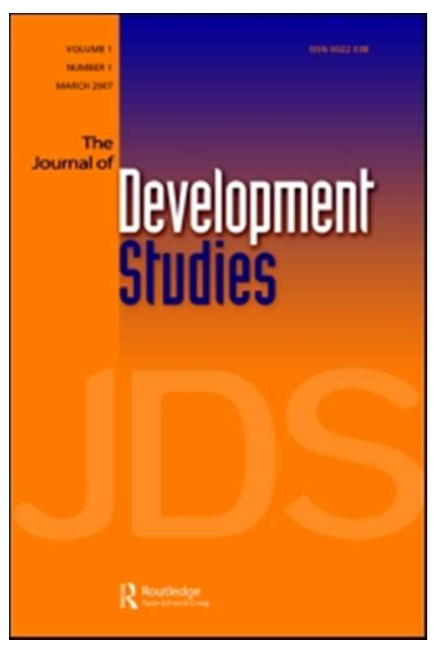

\title{
Do We See Convergence in Institutions? A Cross-Country Analysis
}

\begin{tabular}{|r|l|}
\hline Journal: & Journal of Development Studies \\
\hline Manuscript ID: & FJDS-2013-Aug-0088.R3 \\
\hline Manuscript Type: & Papers in Special Issues \\
\hline Keywords: & $\begin{array}{l}\text { Economic growth < Economics, Economic development < Economics, } \\
\text { Governance < Government, State Policy, \& Ideologies, Institutions < } \\
\text { International relations and Organisations and Agreements }\end{array}$ \\
\hline \multicolumn{2}{|l}{} \\
\hline
\end{tabular}

SCHOLARONE $^{\text {Ix }}$

Manuscripts 


\title{
Do We See Convergence in Institutions? A Cross- Country Analysis
}

\author{
$27^{\text {th }}$ April 2015
}

\begin{abstract}
Differences in the quality of institutions may explain differences in per capita income. Yet, we know relatively little on how institutions evolve. This paper contributes to such knowledge by testing for convergence in legal, bureaucratic and administrative institutional quality. Using cross-section and panel methods on a large sample of countries from the 1970 s to 2010 , we find that countries with initially poor institutions tended to slowly catch up, both when they shared the same initial conditions and when they did not. However, the convergence process seems to be a temporary effect following the end of the Cold War.
\end{abstract}

Keywords: Convergence, Institutions, Institutional Change, Growth, Economic Development

JEL Classification Code: O1, P1, P5 


\section{Introduction}

One of the most important findings in the literature on the determinants of economic growth is that differences in the quality of institutions (defined as the quality of rules, regulations, laws and policies that affect economic incentives to invest in technology, physical capital and human capital) explain in large part differences in per capita income across countries (Hall and Jones, 1999; Acemoglu, Johnson and Robinson, 2001; and Rodrik, Subramanian and Trebbi, 2004). Rich countries, especially those located in the North America, Western Europe, Australia and New Zealand, have better quality institutions and higher per capita income than countries in the developing world. Although some researchers warn on how general such claim is in history (Chang, 2011), the claim is a forceful one. As Acemoglu (2009, p. 123) argues, "there is convincing empirical support for the hypothesis that differences in economic institutions, more than luck, geography or culture, cause differences in incomes per capita". If institutional quality is a crucial determinant of economic growth, we need a better understanding how institutions evolve and under what circumstances they change. One step in this direction is to ask whether we observed convergence in institutions as low-income countries with poor quality institutions adopted the best practice institutions that are prevalent in the richer countries.

A separate literature has long been interested in the phenomenon of convergence. Traditionally, empirical work has been concerned with convergence in national income levels (for example, Quah, 1993; Sala-i-Martin, 1996; Pritchett, 1997; Barro, 2012; Rodrik 2011 and 2013). But the analysis of convergence has extended to other economic phenomena. For example, Khanna et al. (2006) find evidence that economically interdependent countries have similar corporate governance laws protecting stakeholders. Bruno et al. (2012) find partial evidence of convergence in financial systems across OECD economies. Regarding the evolution of development outcomes, Ravallion (2003 and 2012) tests for and finds evidence 
of slow convergence in income distribution, but no evidence of poverty convergence. Deaton (2004) and Canning (2012) look at the evolution of health, showing convergence in life expectancy across countries. Noorbakhsh (2007) extends the concept of convergence to human development, finding evidence of weak absolute convergence over 1975-2002. More closely aligned with the focus of our paper, Keefer and Knack (1997) and Knack (1996) show that the ability of poor countries to catch up to the income levels of rich countries, is determined in large part by the quality of their institutions, and that income convergence is more pronounced in countries with similar levels of institutional quality. If indeed institutions are crucial to income convergence, to what extent do we see catch up in institutional quality between countries? And are contemporary differences in institutional quality between countries transitory or permanent? This paper contributes to this tradition by investigating the convergence of a broad range of institutions that support the functioning of the economy.

We examine the evolution over time and test for convergence in institutional quality across countries. Since the literature on the empirics of economic growth is unclear on the precise type of institution that matters for economic growth (Bardhan, 2005), we use a variety of institutional quality measures, such as the administrative and legal capacity of the state (Besley and Persson, 2011), the rule of law (Rodrik et al., 2004; Haggard and Tiede, 2012), the contracting environment and the security of property rights (Acemoglu, Johnson and Robinson, 2001). We use different data sets and periods of analysis, depending on the institutional variables that we examine, with our sample of countries ranging from 50 to 142 , and our longest period of analysis being 1970-2010. We find that institutional quality tended to (slowly) rise in countries with initially poor institutions, regardless of their initial conditions. This process was faster if economies shared the same structural characteristics and did not depend on the reforms occurring in a specific region or group of countries. The evidence also suggests that a significant acceleration of the convergence process resulted 
from the end of the Cold War. However, such effect on the catch-up of the institutions of transition and developing economies to the high quality institutions of advanced market economies has weakened in the new millennium.

From the econometric point of view, the cross-country regressions presented here are a first pass to understand the evolution of institutional quality around the world. Such results should be interpreted as empirical regularities, which are nonetheless robust, and perhaps constitute a useful base for further research. Our approach relied on the concept of $\beta$ convergence, where cross-section and panel convergence regressions aim at capturing mean reversion phenomena in institutions. However, some literature has emphasised a different statistical notion of convergence (e.g., Quah, 1993): $\sigma$-convergence, which looks at whether the cross-sectional dispersion across countries is decreasing, and for which $\beta$-convergence is a necessary, but not sufficient, condition (e.g., Sala-i-Martin 1996). Some evidence below is consistent with $\sigma$-convergence (and with our regressions). Apart from this, the focus of this paper would nonetheless remain on whether initial conditions matter for differences in institutional quality across countries, namely $\beta$-convergence. This is a question on mean reversion and it is interesting in itself. Paraphrasing Sala-i-Martin (1996), knowing whether institutional quality in poor economies would catch up with that of rich economies could have repercussions on current disparities in income and other development outcomes.

The paper proceeds as follows. In Section 2, we briefly discuss the literature on institutions and review what we may expect on whether institutional quality may converge across countries. Section 3 illustrates the data and the stylised facts on the evolution of institutional quality. Section 4 discusses the methodology and the convergence tests results. Section 5 concludes. 


\section{Why we may expect convergence in institutional quality (and why we may not)}

Should we expect convergence in institutional quality across countries? Lacking a consolidated theory of convergence, the literature on institutional change remains ambivalent about this possibility. Several potential mechanisms for convergence of institutions (or lack of it) have been identified in the literature. These have to do with exogenous factors such as globalization, pressure from international organisations such as the International Monetary Fund or the World Bank, the incidence of wars and the influence of former colonial powers, as well as endogenous factors that have to do with diminishing returns to institutional reforms and with how and whether actors within the economy choose to change institutions in strategic interactions.

For example, La Porta et al (2008, p.327) speculate that convergence in institutional quality will occur as a result of increasing globalization, as it leads to faster exchange of ideas and to higher competition for FDI. This, in turn, will respectively encourage the transfer of legal knowledge and the adoption of good regulations. Larrain and Tavares (2004) find support for this proposition, and show that an increase in the share of FDI in GDP is related to lower corruption for a broad cross-section of countries between 1970 and 1994.

We would also expect that institutional convergence would be more rapid in developing countries since the 1990s with the onset of structural adjustment programmes in Africa and Latin America which led to pressure from the World Bank and the International Monetary Fund on governments of developing countries undergoing structural adjustment to adopt Western-style market institutions, A similar impetus for institutional reform in transition economies came from the end of the Cold War. Thus, the adoption of market institutions of the West in developing and transition economies may have been accelerated by 
the spread of the post-Washington Consensus among donor agencies and Southern governments in the 1990s (Stiglitz, 1998; Kapur and Webber, 2000). In addition, with the end of the Cold War in the early 1990s, both ex command economies and non-socialist developing economies underwent major institutional changes, adopting similar production and exchange mechanisms based on privatisation and deregulation. The transplanting of what were considered as 'best practice' institutions to developing and transition economies occurred in the 1990s in a decade which was widely seen as 'the decade of institutional reform' (Mkandawire, 2012).

However, institutional mono-cropping did not seem to deliver the results in terms of expected economic performance in countries which adopted Western-style institutions (Evans, 2004; Chang, 2007), in part due to the lack of fit with the prevailing social and cultural context (Berkowitz et al., 2003; Djankov et al., 2003; Roland, 2004; Rodrik, 2008) and in part due to the fact that governments in developing countries did not have the capabilities to enforce the successful functioning of these institutions (Khan, 2012). This may have led to a weakening of the incentives of Southern policy-makers to adopt Western-style institutions over time (Mkandawire, 2012).

The role of the incidence of wars in shaping institutions has been pointed out by Besley and Persson (2011) who argue that, in a society where groups compete for power, the incidence of wars supports the demand for common-interest public goods (i.e., defence) that, in turn, increases the incentive to invest in fiscal and legal institutions. The influence of colonial powers in determining the quality of institutions has been noted by Acemoglu, Johnson and Robinson (2001) who suggest that contemporary differences in institutions can be traced to different colonisation policies, with European colonisers more likely to set up 'extractive institutions' that were detrimental to economic development in colonies where 
they did not migrate and settle (such as in Africa and Asia), in contrast to setting up more "European-like" institutions in colonies where they did settle (such as North America).

With respect to endogenous mechanisms of institutional convergence, in analogy with capital accumulation and income convergence, the concept of diminishing returns could also be applicable to institutions, as the early 'units' of institutional reforms are relatively easier and less costly to attain. It would be much more difficult and costly to attain a higher level of institutional quality from an initially high level than a low level. For example, in an economy with poor rule of law, it would be relatively easy to use the army to guarantee some basic order so that production can take place, while in an economy with a developed rule of law, it would be relatively difficult and costly to design reforms that tackle cybercrime.

In addition to such endogenous mechanisms, the literature on institutional change suggest that reforms may not occur because of strategic interactions amongst agents and the distribution of power between social groups, including elites and non-elites. A conflict over the distribution of resources creates insurmountable commitment problems for institutional change. For the rich (poor) cannot commit to compensate the poor (rich) after old rules have been replaced with new ones (Acemoglu, 2003; Bardhan, 2005). As a result, 'bad' institutions can persist. Taking this view further, Acemoglu and Robinson $(2006,2008)$ argue that institutional reforms may be hindered by elites who benefit from existing economic institutions. Political elites who hold power will always have an incentive to maintain the political institutions that give them political power, and the economic institutions that distribute resources to them. Therefore, there would be a persistence of poor quality economic and political institutions in such societies, since the elites who benefit from these institutions would not have any incentives to change them (Acemoglu and Robinson, 2008, 2012). ${ }^{\mathrm{i}}$ 
The above discussion suggests that ultimately, whether economies with poor quality institutions catch up with economies with high quality institutions, and how fast, are a matter of empirical debate as neither the theoretical nor the previous empirical literature provides any clear and unambiguous answer on what we may expect. ${ }^{i i}$ In this paper, we investigate whether there has been a process of catch-up in countries with poor quality institutions through simple convergence tests. Since there is no fully-fledged model of institutional convergence, one may argue that we are doing 'measurement without theory', as Koopmans (1947) remarked. However, lacking a consolidated theoretical model, there is still a lot to gain from providing the stylized facts on institutional convergence, as a base for future research (Kydland and Prescott 1995). Before we proceed to illustrate the convergence tests, we describe the data that we will use and provide some descriptive statistics on the evolution of institutional quality across countries.

\section{Variables and descriptive statistics}

This section illustrates the measures of institutional quality, examining the trends of legal, bureaucratic and administrative institutional quality measures. Since institutions are persistent phenomena and should be analysed over long periods, we concentrate on crosscountry data with the longest temporal (and a substantial geographical) coverage provided by International Country Risk Guide (ICRG, 2012) and the Fraser Institute (Gwartney et al, 2013). The online appendix provides details on each database and on the countries observed.

The ICRG database (ICRG, 2012), constructed by Political Risk Services, covers the 1985-2010 period. ${ }^{\text {iii }}$ The ICRG variables are the most commonly used measures of institutional quality in the empirical literature on institutions and growth (for example, Knack and Keefer 1995, Hall and Jones 1999, and Acemoglu, Johnson and Robinson 2001). The data comes from subjective assessments of foreign investors and business experts. It includes 
three continuous variables (rescaled to range between zero and ten): Rule of Law, Corruption in Government, and Bureaucratic Quality indices. The first one is an indicator of legal capacity of the state; the last two capture the level of bureaucratic and administrative quality. ${ }^{\text {iv }}$

Another subjective measure, which captures significant dimensions of legal capacity, allows to observe the longest period: the Quality of Legal Structure and Security of Property Rights index (Gwartney et al, 2013). This is a component of the Fraser Institute index of Economic Freedom, and is a continuous variable ranging between zero and ten, with a higher score corresponding to higher quality of institutions. This is the only available indicator over a long time span, also for some developing economies. It has, in fact, been recorded every five years from 1970 until 2000 (and every year from 2001 on), but between 1970 and 1975 only fifty countries are observed. Unfortunately, it samples fewer countries than the ICRG database. The index has been assembled over the years from different sources - essentially, but not exclusively, from: the ICRG, the Business Environment Risk Intelligence and the Global Competitiveness Report - and has undergone some changes in definition, although the underlying concept remains unchanged (see, for details, Gwartney et al, 2013). Table 1 shows their trends, comparing economies at different stages of development over 1980-2010. ${ }^{\mathrm{v}}$ 


\begin{tabular}{|c|c|c|c|c|c|c|c|c|}
\hline \multicolumn{9}{|c|}{ Panel (a): Quality of legal structure and security of property rights index } \\
\hline Year & & 1980 & 1985 & 1990 & 1995 & 2000 & 2005 & 2010 \\
\hline Whole sample & $\begin{array}{l}\text { Mean } \\
\text { CV } \\
\mathrm{N}\end{array}$ & $\begin{array}{l}5.01 \\
0.40 \\
90\end{array}$ & $\begin{array}{l}5.09 \\
0.36 \\
110\end{array}$ & $\begin{array}{l}5.31 \\
0.36 \\
111 \\
\end{array}$ & $\begin{array}{l}5.87 \\
0.29 \\
123\end{array}$ & $\begin{array}{l}5.83 \\
0.33 \\
123\end{array}$ & $\begin{array}{l}5.85 \\
0.30 \\
139 \\
\end{array}$ & $\begin{array}{l}5.60 \\
0.29 \\
142\end{array}$ \\
\hline Advanced Economies & $\begin{array}{l}\text { Mean } \\
\mathrm{CV} \\
\mathrm{N}\end{array}$ & $\begin{array}{l}7.19 \\
0.13 \\
28\end{array}$ & $\begin{array}{l}7.05 \\
0.18 \\
30\end{array}$ & $\begin{array}{l}7.55 \\
0.15 \\
30 \\
\end{array}$ & $\begin{array}{l}8.18 \\
0.13 \\
30\end{array}$ & $\begin{array}{l}8.34 \\
0.14 \\
30\end{array}$ & $\begin{array}{l}8.17 \\
0.11 \\
30\end{array}$ & $\begin{array}{l}7.64 \\
0.12 \\
30\end{array}$ \\
\hline Developing Economies & $\begin{array}{l}\text { Mean } \\
\mathrm{CV} \\
\mathrm{N}\end{array}$ & $\begin{array}{l}4.03 \\
0.36 \\
62\end{array}$ & $\begin{array}{l}4.19 \\
0.31 \\
73\end{array}$ & $\begin{array}{l}4.27 \\
0.32 \\
74\end{array}$ & $\begin{array}{l}4.98 \\
0.22 \\
78\end{array}$ & $\begin{array}{l}4.87 \\
0.27 \\
78\end{array}$ & $\begin{array}{l}5.05 \\
0.28 \\
86\end{array}$ & $\begin{array}{l}4.84 \\
0.27 \\
87\end{array}$ \\
\hline Transition Economies & $\begin{array}{l}\text { Mean } \\
\mathrm{CV} \\
\mathrm{N}\end{array}$ & & $\begin{array}{l}5.95 \\
0.21 \\
7\end{array}$ & $\begin{array}{l}6.46 \\
0.13 \\
7\end{array}$ & $\begin{array}{l}5.90 \\
0.19 \\
15\end{array}$ & $\begin{array}{l}5.82 \\
0.14 \\
15\end{array}$ & $\begin{array}{l}5.73 \\
0.17 \\
23\end{array}$ & $\begin{array}{l}5.69 \\
0.12 \\
25\end{array}$ \\
\hline \multicolumn{9}{|c|}{ Panel (b): Bureaucratic Quality index } \\
\hline Whole sample & $\begin{array}{l}\text { Mean } \\
\mathrm{CV} \\
\mathrm{N}\end{array}$ & & $\begin{array}{l}5.07 \\
0.64 \\
124\end{array}$ & $\begin{array}{l}5.17 \\
0.61 \\
131\end{array}$ & $\begin{array}{l}5.74 \\
0.50 \\
130\end{array}$ & $\begin{array}{l}5.44 \\
0.53 \\
140\end{array}$ & $\begin{array}{l}5.35 \\
0.53 \\
140\end{array}$ & $\begin{array}{l}5.47 \\
0.51 \\
139\end{array}$ \\
\hline Advanced Economies & $\begin{array}{l}\text { Mean } \\
\mathrm{CV} \\
\mathrm{N}\end{array}$ & & $\begin{array}{l}8.77 \\
0.19 \\
32\end{array}$ & $\begin{array}{l}8.66 \\
0.21 \\
31 \\
\end{array}$ & $\begin{array}{l}9.33 \\
0.12 \\
30\end{array}$ & $\begin{array}{l}9.38 \\
0.11 \\
30\end{array}$ & $\begin{array}{l}9.21 \\
0.14 \\
30\end{array}$ & $\begin{array}{l}9.21 \\
0.14 \\
30\end{array}$ \\
\hline Developing Economies & $\begin{array}{l}\text { Mean } \\
\mathrm{CV} \\
\mathrm{N}\end{array}$ & & $\begin{array}{l}3.81 \\
0.73 \\
80\end{array}$ & $\begin{array}{l}3.87 \\
0.69 \\
88 \\
\end{array}$ & $\begin{array}{l}4.46 \\
0.51 \\
88\end{array}$ & $\begin{array}{l}4.20 \\
0.52 \\
87\end{array}$ & $\begin{array}{l}.12 \\
0.50 \\
87 \\
\end{array}$ & $\begin{array}{l}4.30 \\
0.46 \\
87\end{array}$ \\
\hline Transition Economies & $\begin{array}{l}\text { Mean } \\
\mathrm{CV} \\
\mathrm{N} \\
\end{array}$ & & $\begin{array}{l}3.75 \\
0.53 \\
12 \\
\end{array}$ & $\begin{array}{l}5.00 \\
0.38 \\
12 \\
\end{array}$ & $\begin{array}{l}5.54 \\
0.41 \\
12 \\
\end{array}$ & $\begin{array}{l}4.89 \\
0.50 \\
23 \\
\end{array}$ & $\begin{array}{l}.84 \\
0.46 \\
23\end{array}$ & $\begin{array}{l}4.83 \\
0.47 \\
22\end{array}$ \\
\hline \multicolumn{9}{|c|}{ Panel (c): Rule of Law index } \\
\hline Whole sample & $\begin{array}{l}\text { Mean } \\
\mathrm{CV} \\
\mathrm{N}\end{array}$ & & $\begin{array}{l}5.40 \\
0.49 \\
124\end{array}$ & $\begin{array}{l}5.12 \\
0.53 \\
131\end{array}$ & $\begin{array}{l}7.18 \\
0.31 \\
130\end{array}$ & $\begin{array}{l}6.56 \\
0.35 \\
140\end{array}$ & $\begin{array}{l}6.32 \\
0.34 \\
140\end{array}$ & $\begin{array}{l}6.17 \\
0.36 \\
139\end{array}$ \\
\hline Advanced Economies & $\begin{array}{l}\text { Mean } \\
\mathrm{CV} \\
\mathrm{N} \\
\end{array}$ & & $\begin{array}{l}8.47 \\
0.23 \\
32 \\
\end{array}$ & $\begin{array}{l}8.34 \\
0.27 \\
31 \\
\end{array}$ & $\begin{array}{l}9.75 \\
0.06 \\
30\end{array}$ & $\begin{array}{l}9.07 \\
0.15 \\
30 \\
\end{array}$ & $\begin{array}{l}8.91 \\
0.11 \\
30 \\
\end{array}$ & $\begin{array}{l}8.86 \\
0.10 \\
30\end{array}$ \\
\hline Developing Economies & $\begin{array}{l}\text { Mean } \\
\mathrm{CV} \\
\mathrm{N} \\
\end{array}$ & & $\begin{array}{l}4.17 \\
0.45 \\
80 \\
\end{array}$ & $\begin{array}{l}3.83 \\
0.48 \\
88 \\
\end{array}$ & $\begin{array}{l}6.11 \\
0.31 \\
88 \\
\end{array}$ & $\begin{array}{l}5.57 \\
0.36 \\
87 \\
\end{array}$ & $\begin{array}{l}5.27 \\
0.35 \\
87 \\
\end{array}$ & $\begin{array}{l}5.09 \\
0.36 \\
87\end{array}$ \\
\hline Transition Economies & $\begin{array}{l}\text { Mean } \\
\mathrm{CV} \\
\mathrm{N} \\
\end{array}$ & & $\begin{array}{l}5.97 \\
0.35 \\
12 \\
\end{array}$ & $\begin{array}{l}6.19 \\
0.31 \\
12 \\
\end{array}$ & $\begin{array}{l}8.44 \\
0.16 \\
12 \\
\end{array}$ & $\begin{array}{l}6.88 \\
0.21 \\
23 \\
\end{array}$ & $\begin{array}{l}6.85 \\
0.16 \\
23 \\
\end{array}$ & $\begin{array}{l}6.71 \\
0.17 \\
22\end{array}$ \\
\hline \multicolumn{9}{|c|}{ Panel (d): Corruption in Government index } \\
\hline Whole sample & $\begin{array}{l}\text { Mean } \\
\mathrm{CV} \\
\mathrm{N}\end{array}$ & & $\begin{array}{l}5.56 \\
0.46 \\
124 \\
\end{array}$ & $\begin{array}{l}5.62 \\
0.43 \\
131 \\
\end{array}$ & $\begin{array}{l}5.87 \\
0.36 \\
130 \\
\end{array}$ & $\begin{array}{l}4.94 \\
0.41 \\
140\end{array}$ & $\begin{array}{l}4.17 \\
0.48 \\
140 \\
\end{array}$ & $\begin{array}{l}4.48 \\
0.42 \\
139 \\
\end{array}$ \\
\hline Advanced Economies & $\begin{array}{l}\text { Mean } \\
\mathrm{CV} \\
\mathrm{N}\end{array}$ & & $\begin{array}{l}8.50 \\
0.21 \\
32\end{array}$ & $\begin{array}{l}8.31 \\
0.20 \\
31\end{array}$ & $\begin{array}{l}8.44 \\
0.18 \\
30\end{array}$ & $\begin{array}{l}7.20 \\
0.28 \\
30\end{array}$ & $\begin{array}{l}7.13 \\
0.22 \\
30\end{array}$ & $\begin{array}{l}7.26 \\
0.22 \\
30\end{array}$ \\
\hline Developing Economies & $\begin{array}{l}\text { Mean } \\
\mathrm{CV} \\
\mathrm{N} \\
\end{array}$ & & $\begin{array}{l}4.37 \\
0.45 \\
80 \\
\end{array}$ & $\begin{array}{l}4.49 \\
0.42 \\
88 \\
\end{array}$ & $\begin{array}{l}4.92 \\
0.32 \\
88 \\
\end{array}$ & $\begin{array}{l}4.25 \\
0.35 \\
87 \\
\end{array}$ & $\begin{array}{l}3.32 \\
0.36 \\
87 \\
\end{array}$ & $\begin{array}{l}3.72 \\
0.30 \\
87 \\
\end{array}$ \\
\hline Transition Economies & $\begin{array}{l}\text { Mean } \\
\mathrm{CV} \\
\mathrm{N}\end{array}$ & & $\begin{array}{l}6.11 \\
0.24 \\
12\end{array}$ & $\begin{array}{l}6.75 \\
0.20 \\
12\end{array}$ & $\begin{array}{l}6.37 \\
0.19 \\
12\end{array}$ & $\begin{array}{l}4.58 \\
0.41 \\
23\end{array}$ & $\begin{array}{l}3.47 \\
0.26 \\
23\end{array}$ & $\begin{array}{l}3.64 \\
0.25 \\
22\end{array}$ \\
\hline
\end{tabular}

The first stylised fact is the gap in institutional quality between advanced economies

and the rest remains wide. Since the 1980s, both developing and advanced economies have,

by the end of the observed period, experienced improvements in the Quality of Legal Structure and Security of Property Rights, in the rule of law and in the bureaucratic quality index. The Corruption in Government index, instead, worsened in both advanced and developing countries over the 1985-2010 period. The transition economies saw a 
deterioration in the quality of the legal system, property rights protection and corruption, but also improvements in measures of bureaucratic quality and rule of law.

A second stylised fact is that the cross sectional dispersion over the whole sample (as expressed by the coefficient of variation), from the beginning to the end period, decreases in all measures. However, the decrease is generally monotonic until 1995, but subsequently the dispersion picks up again or becomes stable, so suggesting that a likely convergence effect in institutional quality has stopped or decelerated. According to all four measures, advanced economies remain a more homogenous group than developing and transition economies, which show greater variability in institutional quality at the end of the period.

\section{Convergence tests}

Since we are interested in whether poorer countries are narrowing (or broadening) their institutional quality gap with richer countries, an appropriate starting point is the statistical notion of convergence that two countries exhibit convergence if the one with lower initial institutional qualityexperiences faster improvements in institutions than the other and so tends to "catch up" with the higher-quality institutions country. Since this is a between country regularity, the corresponding test, based on cross-section data, is to regress the observed relative changes over time on a given measure on the measure's initial values across countries. Let $G_{i t}$ denote the observed institutional quality measure in country $i$ observed at both date $t=0$ and $t=T$, that is, at the beginning and at the end of the sample period respectively. A test equation for institutional quality convergence is then:

$$
\left(\operatorname{lnG}_{i T}-\ln \mathrm{G}_{i 0}\right) / \mathrm{T}=\alpha+\beta \mathrm{G}_{i 0}+\varepsilon_{i} \quad \text { with } i=1, \ldots, N
$$

where the dependent variable is the average annual growth rate in institutional quality, $\alpha$ and $\beta$ are parameters to be estimated and $\varepsilon_{i I}$ is a zero mean error term. ${ }^{\mathrm{vi}}$ According to (1), a negative (positive) estimate of the parameter $\beta$ implies that there is institutional quality 
convergence (divergence). The magnitude of $\beta$ expresses the speed of convergence (divergence). In particular, equation (1) is a test for the hypothesis of unconditional convergence, according to which institutions of countries converge to one another in the long-run independently of their initial conditions, that is, differences are transitory.

To eyeball the data, figure 1 presents the scatter plots, fitting a simple regression line, for the Quality of Legal System and Security of Property Rights, which is the measure with the longest time coverage. Evidence of unconditional convergence is apparent both when the initial value is 1985 and when the plot extends to the earlier initial values (1970 being the earliest), therefore suggesting that economies with weaker institutions in 1985 are expected to catch up with the economies having high-quality institutions to start with. However, the significance and speed of the convergence process can be best assessed when referring to the regression estimates.

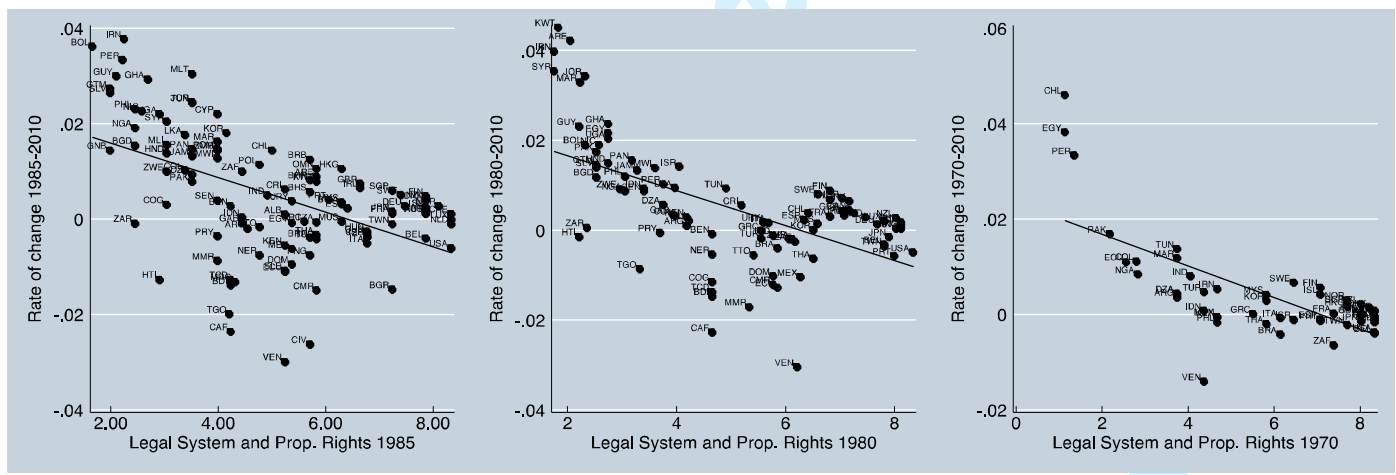

Figure 1 - Initial level of institutional quality vs. subsequent rate of change: various periods

\subsection{Unconditional convergence}

Panel (a) in Table 2 reports unconditional convergence estimates over the period 1985-2010 for the ICRG measures; and over 1985-2010, 1980-2010 and 1970-2010 for the Quality of_Legal System and Security of Property Rights. The estimates show that withincountry institutional quality has been converging since the 1980 s, with the coefficients on initial measures both negative and statistically significant at the one per cent level. To give an 


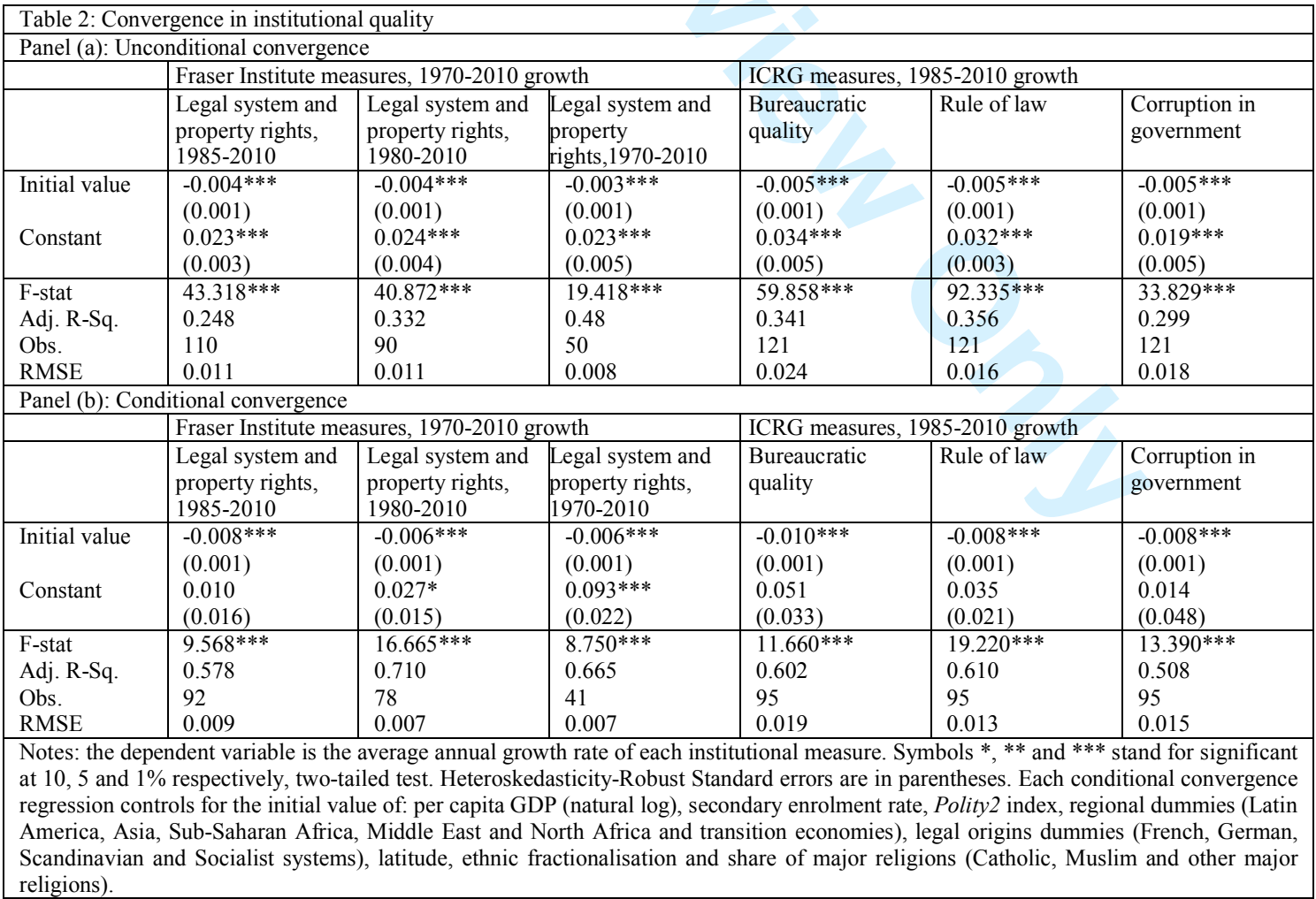




\subsection{Conditional convergence}

Results on unconditional convergence suggest that differences in institutional quality between countries may be closing, but this is a rather slow process. Would this process be faster among countries that share the same structural characteristics? This means considering the conditional convergence hypothesis: countries' institutions converge to one another in the long run, if their structural characteristics are identical (that is, differences may be permanent due to cross-country structural factors). A test equation for institutional quality conditional convergence is then:

$$
\left(\operatorname{lnG}_{i T}-\ln \mathrm{G}_{i 0}\right) / \mathrm{T}=\alpha+\beta \mathrm{G}_{i 0}+\gamma \mathbf{X}_{i 0}+\varepsilon_{i} \quad \text { with } i=1, \ldots, N
$$

Where $\mathbf{X}_{i 0}$ is a set of explanatory variables that account for long-run determinants of institutional change across countries. It includes the following controls: (i) the initial level of per capita GDP (Heston et al. 2011), as institutions can evolve depending on the stage of economic development, for example, see Barro (2012); (ii) the initial level of education, measured by secondary enrolment rate (World Bank 2011b), as the quality of human capital can be positively related to designing functional institutions; (iii) the initial level of political democracy (Savoia et al. 2010), using Polity 2 index. ${ }^{\text {vii }}$ (iv) continent dummies, to capture regional fixed effects; (v) distance from the equator, to capture geographical effects; (vi) legal origins dummies, as proposed by La Porta et al. (1999); (vii) the share of major religions in 1980 (Catholic, Protestant and Muslim), from La Porta et al (1999), to capture the effect of culture; (viii) ethnic fractionalisation, from Alesina et al. (2003), as a proxy for cultural homogeneity.

In equation (2), a negative (positive) estimate of $\beta$ implies conditional convergence (divergence) in institutions. The results, in panel (b) of Table 2, do suggest that institutions in countries with identical structural characteristics converged. The convergence process was 
faster than in the case of unconditional convergence, that is, when countries share the same stage of development, political system, education level and other structural characteristics. But it seems still a process that could take many years. Considering again the first column, the estimated $\beta_{-}$suggests that a country with a low Quality of Legal System and Security of Property Rights index in 1985 will close the gap at an average 0.8 per cent every year (ceteris paribus), which is approximately double the corresponding speed of unconditional convergence. $^{\text {ix }}$

\subsection{Do nonlinearities drive the results?}

The results are generally insensitive to a number of robustness checks reported in the online appendix. Here, however, we illustrate one specific concern: that the results may be picking a 'ceiling effect', i.e., the catching up over time could derive from the mechanical fact that some countries had limited room for improvements in institutional quality if they already had very high initial scores. To address this possibility, we use quantile regression, splitting the sample into terciles, quartiles and quintiles of the dependent variable.

Table 3 shows such regressions for the key convergence tests of the paper. The $\underline{\text { results suggest that the findings of the paper survive well, although with qualifications. For }}$ all three types of quantile regressions, the coefficient of the initial value remains negative and highly significant at the conventional levels for all measures. There are only two exceptions $\underline{\text { to this, relating to the Fraser Institute measure, where the convergence parameter looses }}$ significance in the bottom quintile.

The magnitude of the coefficients tends to be smaller when moving from upper to lower quantiles. To explore this further, we formally test the equivalence of the estimated quantile coefficients at different conditional quantiles. The linear restriction tests in the majority of cases fail reject the null of equality of the estimated coefficients across quantiles. 
The only exceptions are the terciles and quartiles of the rule of law and corruption measures.

\begin{tabular}{|c|c|c|c|c|c|c|c|c|c|}
\hline \multicolumn{10}{|c|}{ Table: Unconditional convergence in institutional quality: quantile regression } \\
\hline \multicolumn{10}{|c|}{ Panel (a): Fraser Institute measures, $1970-2010$ growth } \\
\hline \multicolumn{10}{|c|}{ Dep. Variable: Legal system and property rights, $1985-2010$} \\
\hline & \multicolumn{2}{|l|}{ Terciles } & \multicolumn{3}{|l|}{ Quartiles } & \multicolumn{4}{|l|}{ Quintiles } \\
\hline & $\overline{\text { QR67 }}$ & QR33 & QR75 & QR50 & QR25 & QR80 & QR60 & QR40 & QR20 \\
\hline Constant & $\begin{array}{l}-0.004 * * * \\
(0.001) \\
0.030 * * * \\
(0.004) \\
\end{array}$ & $\begin{array}{l}\frac{-0.002 * * *}{(0.001)} \\
\frac{0.013 * * *}{(0.005)} \\
\end{array}$ & $\begin{array}{l}-0.004 * * * \\
\underline{(0.000)} \\
\underline{0.033 * * *} \\
(0.002) \\
\end{array}$ & $\begin{array}{l}-0.003 * * * \\
0.001) \\
0.023 * * * \\
(0.004) \\
\end{array}$ & $\begin{array}{l}\underline{-0.001 * *} \\
\underline{(0.001)} \\
\underline{0.005} \\
(0.003) \\
\end{array}$ & $\begin{array}{l}\frac{-0.004 * * *}{(0.000)} \\
\underline{0.036 * * *} \\
(0.003)\end{array}$ & $\begin{array}{l}-0.003 * * * \\
0.001) \\
0.027 * * * \\
(0.003) \\
\end{array}$ & $\begin{array}{l}\frac{-0.003 * * *}{(0.001)} \\
\underline{0.020 * * *} \\
(0.004) \\
\end{array}$ & $\begin{array}{l}-0.001 \\
(0.001) \\
0.000 \\
(0.005) \\
\end{array}$ \\
\hline Obs. & $\underline{110}$ & $\underline{110}$ & $\underline{110}$ & $\underline{110}$ & $\underline{110}$ & $\underline{110}$ & $\underline{110}$ & $\underline{110}$ & $\underline{110}$ \\
\hline $\mathrm{H}_{0}$ : all $\beta$ s equal & \multicolumn{2}{|c|}{$\underline{0.1547}$} & \multicolumn{3}{|c|}{$\underline{0.1223}$} & \multicolumn{4}{|c|}{$\underline{\underline{0.1359}}$} \\
\hline $\begin{array}{l}H_{0}: \beta_{075}=\beta_{025} \\
H_{0}: \beta_{025}=\beta_{050} \\
H_{0}: \beta_{075}=\beta_{050}\end{array}$ & \multicolumn{2}{|c|}{ 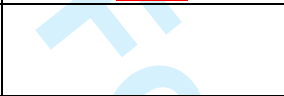 } & \multicolumn{3}{|c|}{$\begin{array}{l}\underline{0.0418} \\
\underline{0.0936} \\
\underline{0.26077}\end{array}$} & \multicolumn{4}{|c|}{ 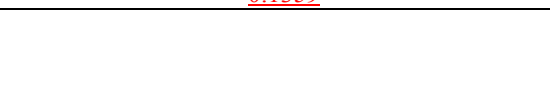 } \\
\hline 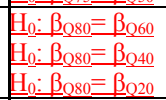 & \multicolumn{2}{|c|}{ 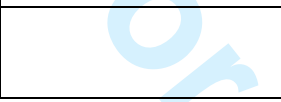 } & & & & \multicolumn{4}{|c|}{$\begin{array}{l}\underline{0.1384} \\
\underline{0.2163} \\
\underline{\underline{0.0305}} \\
\end{array}$} \\
\hline \multicolumn{10}{|c|}{ Dep. Variable: Legal system and property rights, $1980-2010$} \\
\hline & \multicolumn{2}{|c|}{ Terciles } & \multicolumn{3}{|l|}{ Quartiles } & \multicolumn{4}{|l|}{ Quintiles } \\
\hline & QR67 & QR33 & QR75 & QR50 & $\mathrm{QR} 25$ & $\mathrm{QR} 80$ & QR60 & QR40 & QR20 \\
\hline $\begin{array}{l}\text { Initial value } \\
\text { Constant }\end{array}$ & $\begin{array}{l}\frac{-0.003 * * *}{(0.001)} \\
\frac{0.025^{*} * *}{(0.003)} \\
\end{array}$ & $\begin{array}{l}\frac{-0.002 * * *}{(0.001)} \\
\frac{0.012 * * *}{(0.003)} \\
\end{array}$ & $\begin{array}{l}\frac{-0.003 * * *}{(0.001)} \\
\frac{0.027 * * *}{(0.003)} \\
\end{array}$ & $\frac{-0.003 * * *}{\frac{(0.001)}{0.022 * * *}}$ & $\begin{array}{l}\frac{-0.002 * * *}{(0.001)} \\
\frac{0.008 * *}{(0.003)} \\
\end{array}$ & $\begin{array}{l}\frac{-0.004 * * *}{(0.001)} \\
\frac{0.031 * * *}{(0.003)}\end{array}$ & $\begin{array}{l}\frac{-0.003 * * *}{(0.001)} \\
\frac{0.023 * * *}{(0.003)} \\
\end{array}$ & $\begin{array}{l}\frac{-0.003 * * *}{(0.001)} \\
\frac{0.017 * * *}{(0.003)} \\
\end{array}$ & $\begin{array}{l}\frac{-0.001}{(0.001)} \\
\frac{0.004}{(0.005)} \\
\end{array}$ \\
\hline Obs. & 90 & 90 & 90 & 90 & 90 & 90 & 90 & 90 & 90 \\
\hline $\mathrm{H}_{0}$ : all $\beta$ s equal & \multicolumn{2}{|c|}{$\underline{0.2904}$} & \multicolumn{3}{|c|}{$\underline{0.4622}$} & \\
\hline $\begin{array}{l}\mathrm{H}_{0}: \beta_{\mathrm{Q} 75}=\beta_{\mathrm{Q} 25} \\
\mathrm{H}_{0}: \beta_{\mathrm{Q} 25}=\beta_{\mathrm{Q} 50} \\
\mathrm{H}_{0}: \beta_{\mathrm{Q} 75}=\beta_{\mathrm{Q} 50}\end{array}$ & & & \multicolumn{3}{|c|}{$\begin{array}{l}\underline{0.2552} \\
\underline{0.2198} \\
0.8700 \\
\end{array}$} & \multicolumn{4}{|c|}{$\underline{0.4563}$} \\
\hline $\begin{array}{l}\mathrm{H}_{0}: \beta_{\mathrm{O} 80}=\beta_{\mathrm{O} 60} \\
\mathrm{H}_{0}: \beta_{\mathrm{O} 00}=\beta_{\mathrm{O}} \\
\underline{\mathrm{H}}_{0}: \beta_{\mathrm{O} 80}=\beta_{\mathrm{Q} 20}\end{array}$ & & & & & & & $\begin{array}{l}0.2 \\
0.2 \\
0.1 \\
\end{array}$ & $\frac{406}{124}$ & \\
\hline \multicolumn{10}{|c|}{ Dep. Variable: Legal system and property rights, $1970-2010$} \\
\hline & Terciles & & Quartiles & & & Quintiles & & & \\
\hline & QR67 & QR33 & QR75 & QR50 & QR25 & QR80 & QR60 & QR40 & QR20 \\
\hline Initial value & $-0.003 * * *$ & $-0.002 * * *$ & $-0.003 * * *$ & $-0.002 * * *$ & $-0.001 * * *$ & $-0.004 * *$ & $-0.002 * * *$ & $-0.002 * * *$ & $-0.001 * * *$ \\
\hline Constant & $\begin{array}{l}\frac{(0.000)}{0.022 * * *} \\
\frac{(0.003)}{}\end{array}$ & $\begin{array}{l}\overline{(0.000)} \\
\frac{0.010 * * *}{(0.002)}\end{array}$ & $\begin{array}{l}\frac{(0.000)}{0.025 * * *} \\
\frac{(0.002)}{}\end{array}$ & $\begin{array}{l}0.000) \\
\frac{0.016^{* * *}}{(0.003)} \\
\end{array}$ & $\begin{array}{l}(0.000) \\
0.008^{* * *} \\
(0.002) \\
\end{array}$ & $\begin{array}{l}\overline{(0.001)} \\
\frac{0.029 * * *}{(0.008)} \\
\end{array}$ & $\begin{array}{l}\frac{(0.000)}{0.017 * * *} \\
(0.003)\end{array}$ & $\frac{(0.000)}{\frac{0.014 * * *}{(0.003)}}$ & $\begin{array}{l}\frac{(0.000)}{0.007 * *} \\
\frac{(0.003)}{0.003}\end{array}$ \\
\hline Obs. & $\underline{50}$ & 50 & $\underline{50}$ & 50 & $\underline{50}$ & 50 & 50 & $\underline{50}$ & 50 \\
\hline$\underline{H}_{0}:$ all $\beta$ s equal & & $1 \overline{166}$ & & $\underline{0.2341}$ & & 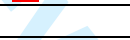 & & 783 & \\
\hline $\begin{array}{l}\mathrm{H}_{0}: \beta_{075}=\beta_{Q 25} \\
\mathrm{H}_{0}: \beta_{Q 25}=\beta_{Q 50} \\
\mathrm{H}_{0}: \beta_{07}=\beta_{050}\end{array}$ & & & & $\begin{array}{l}\underline{0.1456} \\
0.1509 \\
0.4007\end{array}$ & & & & & \\
\hline $\begin{array}{l}\mathrm{H}_{0}: \beta_{\mathrm{Q} 80}=\beta_{\mathrm{Q} 60} \\
\mathrm{H}_{0}: \beta_{\mathrm{O} 80}=\beta_{\mathrm{Q} 40} \\
\mathrm{H}_{0}: \beta_{\mathrm{O} 80}=\beta_{\mathrm{Q} 20}\end{array}$ & & & & & & & & $\begin{array}{l}\frac{914}{708} \\
891 \\
\end{array}$ & \\
\hline Panel (b): ICR & measures, 1 & 85-2010 grow & & & & & 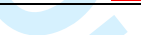 & & \\
\hline \$ep. Variable: & ureaucratic $\mathrm{q}$ & ality & & & & & & & \\
\hline & Terciles & & \begin{tabular}{|l} 
Quartiles \\
\end{tabular} & & & Quintiles & 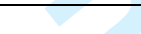 & 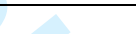 & \\
\hline & QR67 & QR33 & QR75 & QR50 & QR25 & QR80 & QR60 & QR40 & QR20 \\
\hline Initial value & $-0.004^{* * * *}$ & $-0.004 * * *$ & $-0.005^{* * * *}$ & $-0.005 * * *$ & $-0.003 * * *$ & $-0.006 * * *$ & $-0.004 * * *$ & $-0.004 * * *$ & $-0.003 * * *$ \\
\hline Constant & $\frac{(0.000)}{\frac{0.004 * * *}{(0.000)}}$ & $\begin{array}{l}\overline{(0.001)} \\
\frac{0.002 * * *}{(0.000)}\end{array}$ & $\frac{(0.001)}{\frac{0.005 * * *}{(0.001)}}$ & $\begin{array}{l}\overline{(0.001)} \\
\frac{0.004 * * *}{(0.001)}\end{array}$ & $\begin{array}{l}\frac{(0.001)}{0.001 *} \\
(0.000) \\
\end{array}$ & $\begin{array}{l}\overline{(0.001)} \\
\frac{0.006 * * *}{(0.000)}\end{array}$ & $\begin{array}{l}\overline{(0.000)} \\
\frac{0.004 * * *}{(0.001)}\end{array}$ & $\frac{(0.001)}{\frac{0.002 * * *}{(0.000)}}$ & $\begin{array}{l}\frac{(0.001)}{0.001} \\
(0.001) \\
\end{array}$ \\
\hline Obs. & 121 & 121 & $\underline{121}$ & 121 & 121 & 121 & 121 & $\underline{121}$ & 121 \\
\hline$\underline{H}_{0}:$ all $\beta$ s equal & & 861 & & 0.6269 & & & & 955 & \\
\hline $\begin{array}{l}\mathrm{H}_{0}: \beta_{075}=\beta_{025} \\
H_{0}: \beta_{025}=\beta_{050} \\
\underline{H}_{0}: \beta_{077}=\beta_{050}\end{array}$ & & & & $\begin{array}{l}\underline{0.4376} \\
\underline{0.3399} \\
0.8464\end{array}$ & & & & & \\
\hline $\begin{array}{l}\mathrm{H}_{0}: \beta_{\mathrm{O} 80}=\beta_{\mathrm{O} 60} \\
\mathrm{H}_{0}: \beta_{\mathrm{O} 80}=\beta_{\mathrm{O} 40} \\
\mathrm{H}_{0}: \beta_{\mathrm{O} 80}=\beta_{\mathrm{O} 20}\end{array}$ & & & & & & & & $\frac{895}{224}$ & \\
\hline Dep. Variable: & ule of law & & & & & & & & \\
\hline & Terciles & & Quartiles & & & Quintiles & & & \\
\hline & QR67 & QR33 & QR75 & QR50 & QR25 & QR80 & QR60 & QR40 & QR20 \\
\hline $\begin{array}{l}\text { Initial value } \\
\text { Constant }\end{array}$ & $\begin{array}{l}\frac{-0.005 * * *}{(0.000)} \\
\underline{0.004 * * *}\end{array}$ & $\frac{-0.003 * * *}{(0.001)}$ & $\frac{-0.005 * * *}{(0.001)} \frac{0.004 * * *}{0.04}$ & $\frac{-0.003 * * *}{(0.001)} \frac{0.003 * * *}{0.03}$ & $\begin{array}{l}\frac{-0.004 * * *}{(0.001)} \\
\underline{0.002 * * *}\end{array}$ & $\begin{array}{l}\frac{-0.005 * * *}{(0.000)} \\
\underline{0.004 * * * *}\end{array}$ & $\begin{array}{l}\frac{-0.004 * * *}{(0.000)} \\
\underline{0.004 * * *}\end{array}$ & $\begin{array}{l}\frac{-0.003 * * *}{(0.001)} \\
\underline{0.003 * * *}\end{array}$ & $\frac{-0.005 * * *}{\frac{(0.001)}{0.002 * * *}}$ \\
\hline
\end{tabular}




\begin{tabular}{|c|c|c|c|c|c|c|c|c|c|}
\hline & $\underline{(0.000)}$ & $\underline{(0.000)}$ & $\underline{(0.001)}$ & $\underline{(0.001)}$ & $\underline{(0.001)}$ & $\underline{(0.000)}$ & $\underline{(0.001)}$ & $\underline{(0.000)}$ & $\underline{(0.000)}$ \\
\hline Obs. & $\underline{121}$ & $\underline{121}$ & $\underline{121}$ & $\underline{121}$ & $\underline{121}$ & $\underline{121}$ & $\underline{121}$ & $\underline{121}$ & $\underline{121}$ \\
\hline $\mathrm{H}_{0}:$ all $\beta$ s equal & \multicolumn{2}{|c|}{$\underline{0.0279}$} & \multicolumn{3}{|c|}{$\underline{0.0175}$} & \multicolumn{4}{|c|}{$\underline{0.2241}$} \\
\hline $\mathrm{H}_{0}: \beta_{\mathrm{Q75}}=\beta_{\mathrm{Q} 25}$ & & & \multicolumn{3}{|c|}{$\underline{0.7738}$} & & & & \\
\hline$\underline{\mathrm{H}}_{0}: \underline{\beta}_{\mathrm{Q} 25}=\beta_{\mathrm{Q} 50}$ & & & \multicolumn{3}{|c|}{0.4072} & & & & \\
\hline$\underline{\mathrm{H}}_{0}: \underline{\beta}_{\mathrm{Q} 75}=\beta_{\mathrm{Q} 50}$ & & & \multicolumn{3}{|c|}{$\underline{0.0047}$} & & & & \\
\hline $\mathrm{H}_{0}: \beta_{\mathrm{Q} 80}=\beta_{\mathrm{Q} 60}$ & & & & & & & & & \\
\hline $\mathrm{H}_{0}: \beta_{\mathrm{O} 80}=\beta_{\mathrm{O} 40}$ & & & & & & & & 768 & \\
\hline $\mathrm{H}_{0}: \beta_{\mathrm{O} 80}=\beta_{\mathrm{Q} 20}$ & & & & & & & & 125 & \\
\hline \multicolumn{10}{|c|}{ Dep. Variable: Corruption in government } \\
\hline & \multicolumn{2}{|l|}{ Terciles } & \multicolumn{3}{|l|}{ Quartiles } & \multicolumn{4}{|l|}{ Quintiles } \\
\hline & QR67 & QR33 & QR75 & QR50 & QR25 & QR80 & QR60 & QR40 & QR20 \\
\hline Initial value & $-0.003 * * *$ & $-0.006 * * *$ & $-0.003 * * *$ & $-0.003 * * *$ & $-0.007 * * *$ & $-0.004 * * *$ & $-0.003 * * *$ & $-0.004 * * *$ & $-0.007 * * *$ \\
\hline & $(0.001)$ & $(0.001)$ & $(0.001)$ & $(0.001)$ & $(0.001)$ & $(0.001)$ & $(0.001)$ & $(0.000)$ & $(0.001)$ \\
\hline Constant & $0.002 * * *$ & $0.002 * * *$ & $0.002 * * *$ & $0.001 * *$ & $0.002 * * *$ & $0.003 * * *$ & $0.001 * *$ & $0.002 * * *$ & $0.002 * * *$ \\
\hline & $\overline{(0.000)}$ & $\overline{(0.000)}$ & $\overline{(0.000)}$ & $\overline{(0.000)}$ & $(0.000)$ & $(0.001)$ & $\overline{(0.000)}$ & $\overline{(0.000)}$ & $\overline{(0.000)}$ \\
\hline Obs. & $\underline{121}$ & $\underline{121}$ & $\underline{121}$ & $\underline{121}$ & $\underline{121}$ & $\underline{121}$ & $\underline{121}$ & $\underline{121}$ & $\underline{121}$ \\
\hline $\mathrm{H}_{0}:$ all $\beta$ s equal & \multicolumn{2}{|c|}{$\underline{\underline{0.0180}}$} & \multicolumn{3}{|c|}{$\underline{0.0504}$} & \multicolumn{4}{|c|}{$\underline{0.0941}$} \\
\hline $\mathrm{H}_{0}: \beta_{\mathrm{Q} 75}=\beta_{\mathrm{Q} 25}$ & & & \multirow{3}{*}{\multicolumn{3}{|c|}{$\begin{array}{l}\frac{0.0331}{0.0157} \\
\underline{0.9568} \\
\end{array}$}} & \multirow{3}{*}{\multicolumn{4}{|c|}{. }} \\
\hline $\mathrm{H}_{0}: \beta_{\mathrm{Q} 25}=\beta_{\mathrm{Q} 50}$ & & & & & & & & & \\
\hline $\mathrm{H}_{0}: \beta_{\mathrm{Q} 75}=\beta_{\mathrm{Q} 50}$ & & & & & & & & & \\
\hline $\mathrm{H}_{0}: \beta_{\mathrm{Q} 80}=\beta_{\mathrm{Q} 60}$ & \multirow{3}{*}{\multicolumn{2}{|c|}{$V$}} & & & & \multicolumn{4}{|c|}{0.5146} \\
\hline $\mathrm{H}_{0}: \beta_{\mathrm{Q} 80}=\beta_{\mathrm{Q} 40}$ & & & & & & \multicolumn{4}{|c|}{$\underline{0.4640}$} \\
\hline$\underline{\underline{H}}_{0}: \underline{\beta}_{\mathrm{Q} 80}=\underline{\beta}_{\mathrm{Q} 20}$ & & & & & & \multicolumn{4}{|c|}{$\underline{0.0297}$} \\
\hline
\end{tabular}

\subsection{Convergence when institutions are measured with error}

A robustness issue that empirical research on institutions should also address is to what extent measurement error could be affecting the results. In this context measurement error arises from the discrepancy between our set of institutional measures and the 'true' concept of institutions that such measures would like to capture. This could affect both the left- and right-hand sides. Here we ignore the less severe consequences of error from the 'left' (which inflates the standard errors of the estimates, without major consequences in our case), concentrating on the potentially more severe consequences of measurement error from the 'right'.

We assume that (only) the initial level of institutional quality is observed with noise, such that $\mathrm{G}_{i 0}=\mathrm{G}_{i 0}^{*}+e$. If the noise can be approximated by classic errors in variables assumption (that is, measurement error is uncorrelated with the true variable we would like to observe), this is a source of attenuation bias in the OLS estimates of a regression of $\mathrm{G}_{i T}$ on $\mathrm{G}_{i 0}$ (with or without the conditioning variables). In turn, this will lead to an overestimate of the speed of convergence in (1) and (2), implying that our estimates could be optimistic. This is a common problem in the empirical literature on convergence (Temple 1998). 
To give an appreciation of how severe the impact of measurement error could be, we instrument $G_{i 0}$ with its most recent lagged value (although such exercise implies using a reduction in the sample size). Table $\underline{4}$ reports the results. Instrumental variables regressions show that convergence rate estimates are smaller in magnitude, but this is not severe.

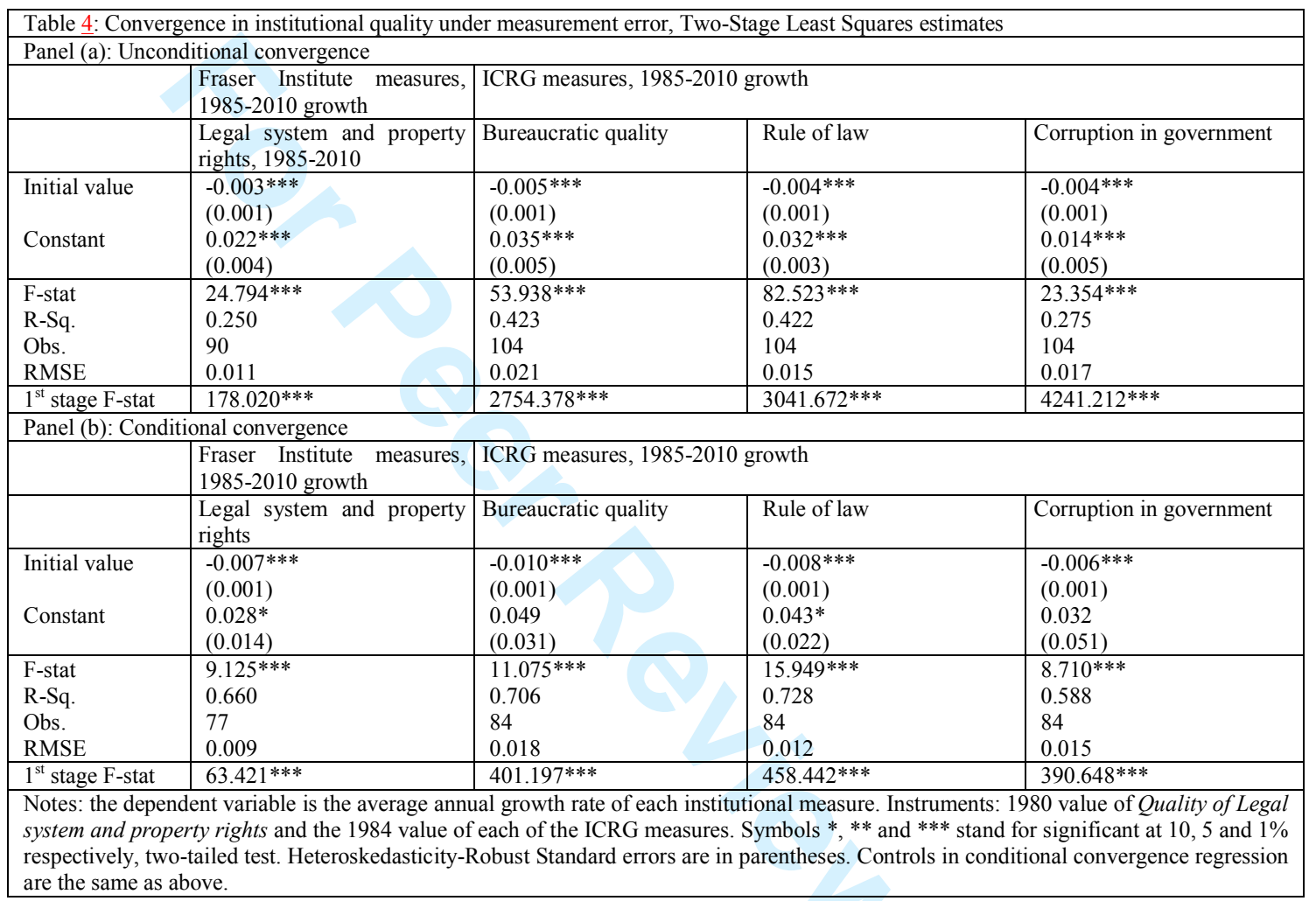

\subsection{Pre-and post-Cold War: has the speed of convergence changed over time?}

As illustrated in section 2, it is possible that the convergence process may have changed pace since the $1990 \mathrm{~s}$. The mutated conditions of international politics, following the end of the Cold War, and the ensuing change in the approach to development policy, with the spread of Washington Consensus and its emphasis on institutional reforms, could have started a process of institutional change fostering convergence. The corresponding testable hypothesis is that the speed of convergence has accelerated over time, which is equivalent to testing if the speed of convergence $\beta$ has been constant or has become larger in magnitude since the 1990 s. 
We do this by reinvestigating conditional and unconditional convergence with panel methods. An unbalanced panel with $\mathrm{N}>\mathrm{T}$ is formed by dividing the period under scrutiny into five-year episodes, starting at the beginning of the earliest available period (for example, 1985-1989, 1990-1995 and so on). Since the Cold War ended approximately in 1990, such temporal structure can capture whether the speed of convergence was faster in the period immediately following the end of the Cold War as compared to the preceding historical period. ${ }^{\mathrm{x}} \mathrm{A}$ test equation for institutional quality convergence in such setting is:

$$
\mathrm{g}_{i t}=\alpha+\lambda_{t}+\alpha_{i}+\beta_{l} \mathrm{G}_{i t 0}+\sum_{t=2}^{T} \beta_{t} \cdot \lambda_{t} G_{i t 0}+\varepsilon_{i t}
$$

The dependent variable in this case is the average annualised growth rate in institutional quality over each of the five-year episodes and $G_{i t 0}$ is its initial value. The term $\alpha_{i}$ captures countries' fixed effects. The symbol $\lambda_{t}$ represents the time effects capturing common shocks, and the 1985-1989 period is the omitted category to separate the post-Cold War period from the historical conditions preceding this period. Like in a Difference-inDifferences approach, the interaction between the time dummies (minus the benchmark one) and the initial level of institutions allows testing for differences in the convergence parameter across time periods. According to (3), the sign and magnitude of the effect of initial institutional quality on its subsequent growth depends on the historical period. Hence, the partial effect will be $\beta_{1}+\beta_{j} \lambda_{j}$. Because a panel approach can account for countries' fixed effects, this exercise responds also to the concern that estimates of conditional convergence may be downward biased if initial institutional quality is positively correlated to countryspecific persistent characteristics allowing certain countries to have high-quality institutions (for example, state history and organisation, political culture and tradition). 


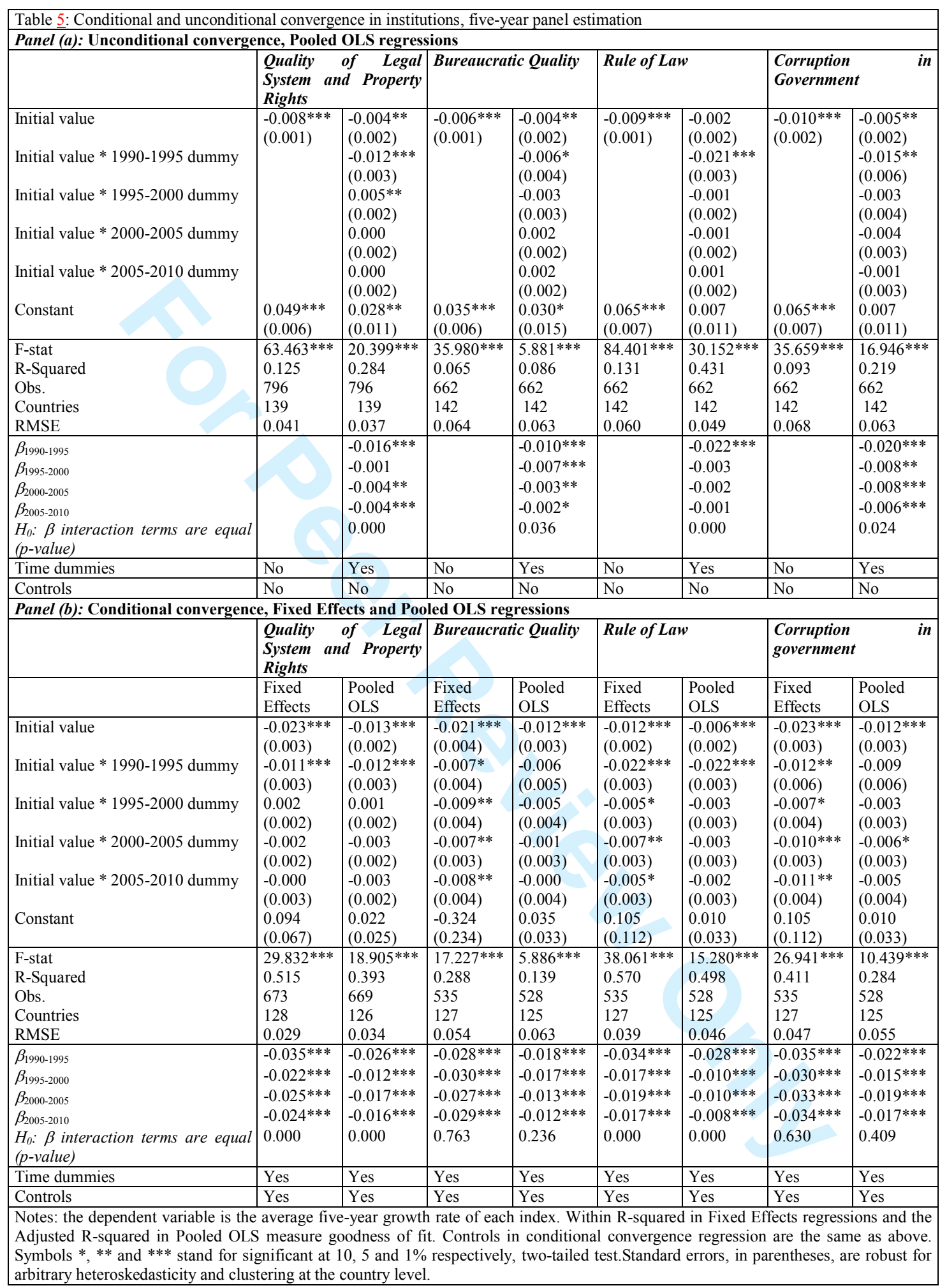

Table $\underline{5}$ presents Pooled OLS and Fixed Effects estimates for our four core measures.

By construction, Fixed Effects regressions are always a test of conditional convergence, as they condition on all time-invariant factors. Pooled OLS regressions, instead, are used to test 
for unconditional convergence if they do not control for any countries' structural characteristics. When they do, then Pooled OLS is used as a useful benchmark against their Fixed Effects counterpart to assess the bias in the convergence parameter due to countryspecific persistent characteristics (for example, Rodrik 2013).

In line with our expectations, Pooled OLS estimates unambiguously confirm the evidence of unconditional convergence. But when such regressions include the interaction terms, these indicate that there has been much stronger convergence for the 1990-1995 period, which testifies of the impact of the end of the Cold War. However, adding the interaction terms also shows that there is no evidence of stronger convergence in more recent five-year periods, suggesting that most of the speed of unconditional convergence seen in cross-section results may be due to a temporary end-of-Cold-War effect. This runs contrary to the expectation that the spread of the Washington Consensus facilitated the adoption of higher quality institutions and therefore catch-up.

On the other hand, Fixed Effects regressions show evidence of stronger conditional convergence in all periods after 1990, apart from one case. Moreover, the general trend in Fixed Effects regressions is to show stronger conditional convergence than previously seen in cross-section estimates. The comparison with their Pooled OLS counterpart suggests that without conditioning on country-specific persistent characteristics would result in substantive underestimation of conditional convergence. But can we rely on Fixed Effects estimates to express the 'true' conditional convergence rate? They seem suspiciously large in magnitude, because of the concomitant role of two forces.

First, since the dependent variable has its principal variation in time (rather than across countries), while all the important variation in the explanatory variable is across countries, Fixed Effects estimates may be shoehorning the data on growth in institutional 
quality and its initial level into a spurious relationship with each other. ${ }^{\text {xi }}$ In particular, conditioning out country fixed effects may overestimate, in magnitude, the speed of convergence. ${ }^{\text {xii }}$ Second, since panel convergence regressions are a reparameterisation of a dynamic panel model linking final level of institutional quality to its initial value, it is known in the convergence and panel econometrics literature that Fixed Effects regressions tend to overestimate the convergence rate, unless the time dimension tends to be large (Barro, 2012). The above discussion implies that the "true" value of the conditional convergence parameters lies somewhere between Fixed Effects estimates, which tend to overestimate it and so represent the "upper bound", and Pooled OLS estimates, which are biased toward zero due to omitted time-invariant variables. Both are useful reference points.

\subsection{Discussion}

Cross-section and panel convergence regressions find evidence of conditional and unconditional convergence over the $1970-2010$ period in measures of legal, administrative and bureaucratic institutional quality, as well as the quality of the contracting environment and the enforcement of private property rights. Such results do not depend on the performance of specific regions in the developing world or of the transition economies. They hold also when accounting for measurement error and are robust to checks for outliers, influential observations and nonlinearity. Our findings suggest that institutions converged regardless of economies initial conditions. However, this seems a rather slow process and most of it resulted from a major historical event, such as the end of the Cold War. By contrast, the conditional convergence estimates suggest that sharing the same structural characteristics has significantly enhanced the institutional 'catch-up' amongst economies.

What are the implications for institutional change? The convergence regressions presented here show and quantify to what extent institutions are persistent. The results seem to suggest that the group of countries having high-quality institutions today would largely be 
the same in the future. This seems to support the view that institutions are path dependent, as has been argued by historical institutionalists (Mahoney 2000). Even when inefficient, a given set of institutions may be kept in place as they serve the interests of influential minorities (Acemoglu and Robinson 2006, 2008). It is likely that, where extractive economic and political institutions exist, ruling elites may not act to replace them with more inclusive institutions if it is not in their interest to do so (Acemoglu and Robinson 2012). Theoretically, it is also possible to conjecture that institutional diversity around the world may be the outcome of a mutually self-reinforcing equilibrium where the existence of a set of institutions in one part of the world may need the existence of a different set of institutions elsewhere (Acemoglu, Robinson and Verdier 2012).

Institutions may also change as a result of epochal historical events, for example, as argued in Acemoglu, Johnson and Robinson (2001). Being the end of the Cold War one such event, the evidence presented here is consistent with the conjecture that the ensuing wave of institutional reforms in the developing world has accelerated the convergence process, in order to mimic institutions maximising market freedom and private property that are typically found in Anglo-American countries (Chang 2011). However, the acceleration in convergence has been a short-lived effect, and seems to have quickly slowed down or disappeared in the new millennium. This weakening of convergence in recent periods, instead, seems compatible with the view that "institutional mono-cropping", as adoption of Western-style institutions in the South, may not have been as successful as expected due to developing economies-specific constraints (Berkowitz et al., 2003; Roland, 2004; Rodrik, 2008; Khan, 2012; Chang, 2007). 


\section{Conclusions}

This paper is concerned with the evolution and change of institutions across countries and over time. We ask whether contemporary differences in the quality of institutions between countries have become wider or narrower. Neither the theoretical nor the previous empirical literature provide clear guidance on whether we should expect the institutions of low-income countries to converge to those of high-income countries. So we let the data speak for themselves and address whether we observed institutional 'catch-up' across the world by presenting cross-section and panel data tests of convergence on a wide array of institutional measures.

The results suggest that developing economies experienced improvements in institutional quality, reducing the gap with advanced economies. We find persuasive evidence for conditional convergence in institutions from the 1980s (or even the 1970s) to 2010. There has been a significant negative correlation between the initial institutional quality measure and its subsequent change in countries with similar structural characteristics, such as the initial levels of income, human capital, and political democracy, as well as similar social and cultural characteristics. Convergence regressions also find evidence of unconditional convergence, implying that initial conditions are irrelevant for differences in institutional quality over the period studied, but it was a rather slow catch-up process. Hence, differences in institutional quality between countries are going to persist for a long time.

The change in the evolution of international politics since the 1980s may be a key factor explaining the observed convergence process. The political and economic systems of many countries have increasingly favoured institutions that restrict arbitrary actions of rulers and bureaucrats and have become increasingly based on market freedom (for example, Huntington (1991) documents the advancement of political democracy). Indeed, we find 
1

2

3

4

5

6

7

8

9

10

11

12

13

14

15

16

17

18

19

20

21

22

23

24

25

26

27

28

29

30

31

32

33

34

35

36

37

38

39

40

41

42

43

44

45

46

47

48

49

50

51

52

53

54

55

56

57

58

59

60

robust evidence that the end of the Cold War was followed by acceleration in institutional quality convergence. But this effect was temporary and had weakened considerably or disappeared in the new millennium, although it is not clear why. This suggests that "better" quality institutions may not necessarily supplant weak institutions in developing countries.

Whatever the reasons for the observed institutional diversity across the world, the relative lack of convergence in institutional quality since the mid 1990s suggests that the lack of absolute convergence in per capita incomes observed in the twentieth century (Pritchett, 1997) may well persist for some time to come in the twenty-first century. 


\section{References}

Acemoglu, D. (2009). Introduction to Modern Economic Growth. Princeton: Princeton University Press.

Acemoglu, Daron (2003). Why not a political Coase theorem? Social conflict, commitment and politics. Journal of Comparative Economics, 31: 620-652.

Acemoglu, D. and Robinson J. A. (2012). Why Nations Fail: The Origins of Power, Prosperity and Poverty. London: Profile Books.

Acemoglu, Daron and James A. Robinson (2008). Persistence of power, elites and institutions. The American Economic Review, 98: 267-293.

Acemoglu, Daron and James A. Robinson (2006). De Facto political power and institutional persistence. The American Economic Review, 96: 325-330.

Acemoglu, Daron, Johnson, Simon and James A. Robinson (2001). The colonial origins of comparative development: an empirical investigation. The American Economic Review, 91: 1369-1401.

Acemoglu, Daron, James A. Robinson and ThierryVerdier (2012) "Can't We All Be More Like Scandinavians? Asymmetric Growth and Institutions in an Interdependent World", MIT Department of Economics Working Paper No. 12-22.

Bardhan, Pranab (2005). Institutions matter, but which ones?. Economics of Transition, 13(3): 499-532.

Barro R.J. (2012), “Convergence and Modernization Revisited", NBER Working Paper 18295.

Berkowitz D., Pistor K. and Richard J-F. (2003) Economic Development, Legality, and the Transplant Effect. European Economic Review, 47: 165-195.

Besley, T. \&Persson T. (2011). Pillars of Prosperity: The Political Economics of Development Clusters. Princeton: Princeton University Press.

Blackburn, K., N. Bose and M.E. Haque (2006). The Incidence and Persistence of Corruption in Economic Development. Journal of Economic Dynamics and Control, 30: 2447-2467.

Bruno G., De Bonis R. and Silvestrini A. (2012) Do Financial Systems Converge? New Evidence From Financial Assets in OECD Countries. Journal of Comparative Economics, 40: 141-155.

Canning D. (2012) Progress in Health Around the World. Journal of Development Studies, 48(12): $1784-1798$

Chang, Ha-Joon (2011). "Institutions and economic development: Theory, Policy and History”. Journal of Institutional Economics, 7(4): 473-498.

Chang, H.-J. (2007). Understanding the relationship between institutions and economic development. In Chang, H.-J. (Ed.), Institutional Change and Economic Development (pp. 17-34), New York: United Nations University Press.

Choi, Imai (2013). Spurious fixed effects regression. Oxford Bulletin of Economics and Statistics, 75(2): 297-306.

Deaton A. (2004) Health in an Age of Globalization, Brookings Trade Forum 2004, Brookings Institution Press, pp.83-130. 
Djankov, Simeon, Glaeser, Edward, La Porta, Rafael, Lopez-de-Silanes, Florencio and Andrei Shleifer (2003). The new comparative economics. Journal of Comparative Economics, 31: 595-619.

Evans, Peter (2004). Development as institutional change: the pitfalls of monocropping and the potentials of deliberation. Studies in Comparative International Development, 38(4): 3052 .

Glaeser, E.L., R. La Porta, F. Lopez-de-Silanes, and A. Shleifer (2004). Do Institutions Cause Growth?. Journal of Economic Growth, 9(3): 271-303.

Gwartney, J.G., Robert Lawson, and Joshua Hall (2013). Economic Freedom of the World: 2013Annual Report. Vancouver: Fraser Institute, 2013. Available at www.freetheworld.com.

Haggard, Stephen and Lydia Tiede (2012). The rule of law and economic growth: where are we?.World Development, 39(5): 673-685.

Hall, Robert and Charles I. Jones (1999). Why do some countries produce so much output per worker than others?. Quarterly Journal of Economics, 114: 83-116.

Huntington, Samuel, 1991, The Third Wave: Democratization in the Late Twentieth Century (Norman: University of Oklahoma Press).

ICRG (2012). "International Country Risk Guide Researchers Dataset, Table 3B". The Political Risk Services Group, third edition.

Kapur, D. and R. Webber (2000), 'Governance-related Conditionalities of the IFIs', G-24 Discussion Paper Series, no. 6, Geneva: UNCTAD.

Khan, Mustaq (2012). Governance and growth: history, ideology and methods of proof, in Noman, Akbar, Botchwey, Kwesi, Stein, Howard and Joseph Stiglitz (eds.), Good growth and governance in Africa, Oxford: Oxford University Press: 51-79.

Khanna T., Kogan J. and Palepu K. (2006) "Globalization and Similarities in corporate Governance: A Cross-Country Analysis", Review of Economics and Statistics, 88(1): 69-90

Keefer P. and Knack S. (1997) "Why Don't poor Countries Catch Up? A Cross-National Test of an Institutional Explanation", Economic Inquiry, 35: 590-602.

Knack S. (1996) "Institutions and the Convergence Hypothesis: The Cross-National Evidence", Public Choice, 87: 207-228

Knack, Stephen and Philip Keefer (1995). Institutions and economic performance: crosscountry tests using alternative institutional measures. Economics and Politics, 7(3): 207-228.

Koopmans, Tjalling C., 1947. Measurement without theory. Review of Economics and Statistics 29, 161-172.

Kydland, Finn E., Prescott, Edward C., 1995. Business cycles: real facts and a monetary myth. Federal Reserve Bank of Minneapolis Quarterly Review, 14, 3-18.

La Porta, Rafael, Lopez-de-Silanes, Florencio and Andrei Shleifer (2008). The economic consequences of legal origins. Journal of Economic Literature, 46(2): 285-332.

La Porta, R., Lopez-de-Silanes, F., Andrei S. and Vishny R. (1999). The quality of government. Journal of Law Economics and Organization, 15(1): 222-279.

Larrain, F.B and J. Tavares (2004). Does Foreign Direct Investment decrease Corruption. Cuadernos De Economia, 41: 217-230. 
Mahoney, James (2000). Path Dependence in Historical Sociology. Theory and Society 29:4:507-548.

Mkandawire, Thandika (2012). Institutional monocropping and monotasking in Africa, in Noman, Akbar, Botchwey, Kwesi, Stein, Howard and Joseph Stiglitz (eds.), Good growth and governance in Africa, Oxford: Oxford University Press: 80-113.

Noorbakhsh, F. (2007) International convergence or higher inequality in human development? Evidence for 1975-2002. In: Mavrotas, G. and Shorrocks, A.F. (eds.) Advancing Development: Core Themes in Global Economics. Palgrave Macmillan, Basingstoke, UK, pp. 149-167.

Pritchett, Lant (1997). Divergence, big time. Journal of Economic Perspective, 11(3): 3-17.

Quah, Danny (2003). One third of the world's growth and inequality, in Eicher, Theo and Stephen J. Turnovsky (eds), Growth and Inequality: Issues and Policy Implications, Cambridge: MIT Press: 27-58.

Quah, Danny (1993). Galton's Fallacy and tests of the convergence hypothesis.Scandinavian Journal of Economics, 95: 427-443.

Ravallion M. (2012) "Why Don't We See Poverty Convergence", American Economic Review, 102(1): 504-523.

Ravallion M. (2003) “Inequality Convergence”, Economics Letters, 80: 351-356.

Rodrik D. (2013), "Unconditional Convergence in Manufacturing”, Quarterly Journal of Economics, 128(1): 165-204.

Rodrik D. (2011), “The Future of Economic Convergence”, NBER Working Paper 17400.

Rodrik, Dani (2008). Second-best institutions. American Economic Review: Papers \& Proceedings, 98(2): 100-104.

Rodrik, Dani, Subramanian, Arvind and Francesco Trebbi (2004). Institutions rule: the primacy of institutions over geography and integration in economic development. Journal of EconomicGrowth, 91:131-165.

Roland, Gérard (2004). Understanding institutional change: fast-moving and slow-moving institutions. Studies in Comparative International Development, 38(4): 109-131.

Sala-i-Martin, Xavier X. (1996). The classical approach to convergence analysis. The Economic Journal, 106(437): 1019-36.

Savoia A., Easaw J., McKay A. (2010) Inequality, Democracy, and Institutions: A Critical Review of Recent Research. World Development, 38(2): 142-154

Savoia, A. and K. Sen (2014). Measurement, Evolution, Determinants and Consequences of State Capacity: A Review of Recent Research. Journal of Economic Surveys, forthcoming.

Stiglitz, Joseph (1998). Broader goals and more instruments: towards the post-Washington consensus, UNU-WIDER Annual Lecture, Helsinki.

Temple, J. R. W. (1998), Robustness tests of the augmented Solow model. J. Appl. Econ., 13: $361-375$.

World Bank (2011a).Worldwide Governance Indicators (WGI) project. Available at: http://info.worldbank.org/governance/wgi/index.asp.

World Bank (2011b) World Development Indicators 2011, http://data.worldbank.org/datacatalog/world-development-indicators. 
i Similarly, Blackburn, Bose and Haque (2006) show that economic development and corruption may be jointly determined such that there may exist multiple long-run equilibria where it is difficult to switch from a state of high corruption and low economic development to a state of low corruption and high economic development.

${ }^{\text {ii }}$ It should be noted that the theoretical literature on institutional change suggests that the rate of convergence may differ across different types of institutions. For example, Acemoglu and Robinson (2008) show that both institutional change and persistence may coexist in a given country context - while political institutions change frequently (e.g. from a dictatorship to a democracy), the equilibrium process for economic institutions remains unchanged, leading to persistence of extractive institutions.

iii To be precise, this database starts in 1984, but observes fewer countries in that year (106) than in 1985 (124). Moreover, we start from 1985 for ease of comparison with the Fraser Institute data, our other core variable.

${ }^{\text {iv }}$ A criticism of ICRG and other data-bases on institutional quality has been made by Glaeser et al (2004) that these measures are conceptually ambiguous de facto assessments of institutional outcomes, and do not adequately capture the rules and laws that constrain economic and political behavior. While we accept this criticism of perceptions based measures of institutions, there are equally challenging issues of measuring institutional quality by de jure institutions such as the laws and rules in a particular society, given the weak enforcement of these rules and laws in developing countries (Savoia and Sen 2014).

${ }^{v}$ In table 1, samples sizes may vary over time, especially for transition economies. The risk is that such variation may bias the comparisons. However, the results obtained by keeping the sample invariant over time (not reported here, but available upon request) show little sensitivity.

${ }^{\mathrm{vi}}$ Convergence tests based on absolute changes (available in the online appendix) give consistent results, showing that our findings are insensitive to changing the functional form. Incidentally, as one anonymous referee remarked, there is some doubt on whether one should use linear regression methods with governance quality data as dependent variables, as most literature where institutions measures is the dependent variable does. One should consider limited dependent variables methods, but the choice is not straightforward though. Such methods, while offering a better fit of the data, are more demanding in terms of the assumptions they require (as well as less developed in terms of allowing for causal estimation). In our case, however, the dependent variables are continuous and assume a broad range of values. The 1985-2010 growth rate of the Legal system and security of property rights variable shows the largest range: 110 different values, while the growth rate of the Bureaucratic Quality variable shows the smallest range: 28 different values.

vii The speed of convergence coefficient indicates that countries one standard deviation below the mean will close the gap at an average $0.65 \%$.

viii We experiment also with other democracy variables: the Constraints on the Executive index and Vanhanen's index. Our results are unchanged. Furthermore, we controlled for the initial level of income inequality, using the Gini index. The results are similar to those included here, but the sample sizes are significantly smaller. 
ix A standard deviation decrease in the initial level of institutional quality implies that the subsequent annualized rate of change will be $1.46 \%$ higher; that is, a country one standard deviation below the mean level of institutional quality will close the gap at an average $1.46 \%$ every year.

${ }^{\mathrm{x}}$ The end of the Cold War as a state of political and military tension between the USA and the USSR dates back to $3^{\text {rd }}$ December 1989, when the American and Soviet leaders declared its end at the Malta Summit. However, the USSR officially dissolved on $25^{\text {th }}$ December 1991.

${ }^{x i}$ For example, the proportion of the total variation in the initial value of the Bureaucratic Quality index due to the between variation is 76 per cent and the same proportion of total variation of its growth rate is, instead, 11 per cent. Similarly, the fraction of total variation in the initial value of the Quality of Property Rights and Legal System index due to the variation across countries is 65 per cent, while for its growth rate is 10 per cent. The other measures show the same patterns.

${ }^{x i i}$ Quah (2003) first raised similar issues in the context of the literature on inequality and growth. This is a special case of spurious regression that econometric theory has now begun to formalise (Choi 2013). 
2

3

Table A1: List of countries

\begin{tabular}{|c|c|c|}
\hline Developing economies & Madagascar MDG & Germany DEU \\
\hline Angola AGO & Maldives MDV & Denmark DNK \\
\hline United Arab Emirates ARE & Mexico MEX & Spain ESP \\
\hline Argentina ARG & Mali MLI & Finland FIN \\
\hline Burundi BDI & Myanmar MMR & France FRA \\
\hline Benin BEN & Mongolia $\mathrm{MNG}$ & United Kingdom GBR \\
\hline Burkina Faso BFA & Mozambique $\mathrm{MOZ}$ & Greece GRC \\
\hline Bangladesh BGD & Mauritania MRT & Hong Kong HKG \\
\hline Bahrain BHR & Mauritius MUS & Ireland IRL \\
\hline Bahamas BHS & Malawi MWI & Iceland ISL \\
\hline Belize BLZ & Malaysia MYS & Israel ISR \\
\hline Bolivia $\mathrm{BOL}$ & Namibia NAM & Italy ITA \\
\hline Brazil BRA & Niger NER & Japan JPN \\
\hline Bhutan BTN & Nigeria NGA & Korea KOR \\
\hline Botswana BWA & Nicaragua NIC & Luxemburg LUX \\
\hline Central African Republic $\mathrm{CAF}$ & Nepal NPL & Malta MLT \\
\hline Chile CHL & Oman OMN & Netherlands NLD \\
\hline Ivory Coast CIV & Pakistan PAK & Norway NOR \\
\hline Cameroon CMR & Panama PAN & New Zealand NZL \\
\hline Congo $\mathrm{COG}$ & Peru PER & Portugal PRT \\
\hline Colombia COL & Philippines PHL & Singapore SGP \\
\hline Comoros COM & Papua New Guinea PNG & Sweden SWE \\
\hline Cape Verde CPV & Paraguay PRY & Taiwan TWN \\
\hline Costa Rica CRI & Qatar QAT & United States USA \\
\hline Cuba CUB & Rwanda RWA & Transition economies \\
\hline Djibouti DJI & Saudi Arabia SAU & Albania ALB \\
\hline Dominica DMA & Sudan SDN & Armenia ARM \\
\hline Dominican Republic DOM & Senegal SEN & Azerbaijan AZE \\
\hline Algeria DZA & Solomon islands SLB & Bulgaria BGR \\
\hline Ecuador ECU & Sierra Leone SLE & Bosnia-Herzegovina BIH \\
\hline Egypt EGY & El Salvador SLV & Belarus BLR \\
\hline Eritrea ERI & Sao Tome and Principe STP & China CHN \\
\hline Ethiopia ETH & Suriname SUR & Czech Rep. CZE \\
\hline Fiji FJI & Swaziland SWZ & Estonia EST \\
\hline Gabon GAB & Seychelles SYC & Georgia GEO \\
\hline Ghana GHA & Syria SYR & Croatia HRV \\
\hline Guinea GIN & 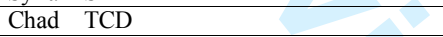 & Hungary HUN \\
\hline Gambia GMB & Togo TGO & Kazakhstan KAZ \\
\hline Guinea-Bissau GNB & Thailand THA & Kirghizstan KGZ \\
\hline Equatorial Guinea GNQ & Tonga TON & Cambodia KHM \\
\hline Grenada GRD & Trinidad and Tobago TTO & Laos LAO \\
\hline Guatemala GTM & Tunisia TUN & Lithuania LTU \\
\hline Guyana GUY & Turkey TUR & Latvia LVA \\
\hline Honduras HND & Tanzania TZA & Moldova MDA \\
\hline Haiti HTI & Uganda UGA & Macedonia MKD \\
\hline Indonesia IDN & Uruguay URY & Poland POL \\
\hline India IND & St. Vincent \& Grenadine VCT & North Korea PRK \\
\hline Iran IRN & Venezuela VEN & Romania ROM \\
\hline Jamaica JAM & Vanuatu VUT & Russia RUS \\
\hline Jordan JOR & Yemen YEM & Slovak Rep. SVK \\
\hline Kenya KEN & South Africa ZAF & Slovenia SVN \\
\hline Kiribati KIR & Zambia ZMB & Tajikistan TJK \\
\hline St. Kitts \& Nevis KNA & Zimbabwe ZWE & Ukraine UKR \\
\hline Kuwait KWT & Advanced economies & Uzbekistan UZB \\
\hline Lebanon LBN & Australia AUS & Vietnam VNM \\
\hline Libya LBY & Austria AUT & 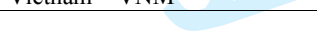 \\
\hline St. Lucia LCA & Belgium BEL & \\
\hline Sri Lanka LKA & Canada CAN & \\
\hline Lesotho LSO & Switzerland CHE & \\
\hline Morocco MAR & Cyprus CYP & \\
\hline
\end{tabular}


Table A2: Definition of the variables

\begin{tabular}{|c|c|}
\hline \multicolumn{2}{|c|}{ Panel (a): Fraser Institute (Gwartneyet al 2013) } \\
\hline $\begin{array}{l}\text { Quality of Legal } \\
\text { System and Security } \\
\text { of Property Rights }\end{array}$ & 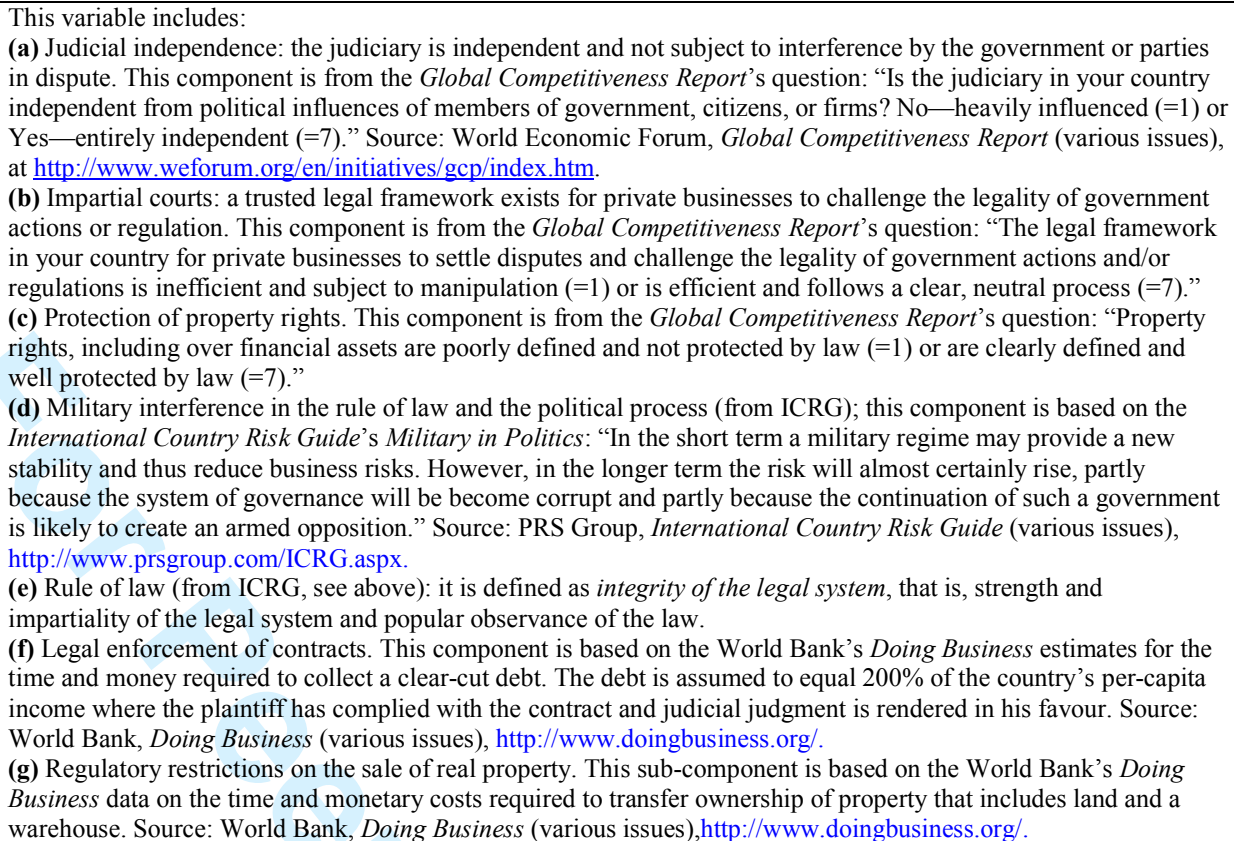 \\
\hline \multicolumn{2}{|c|}{ Panel (b): ICRG measures (ICRG 2012) } \\
\hline Bureaucratic quality & $\begin{array}{l}\text { High scores indicate "an established mechanism for recruitment and training," "autonomy from political pressure," } \\
\text { and "strength and expertise to govern without drastic changes in policy or interruptions in government services" } \\
\text { when governments change. }\end{array}$ \\
\hline Rule of law & $\begin{array}{l}\text { This variable, also known as 'Law and Order Tradition', "reflects the degree to which the citizens of a country are } \\
\text { willing to accept the established institutions to make and implement laws and adjudicate disputes." Higher scores } \\
\text { indicate: "sound political institutions, a strong court system, and provisions for an orderly succession of power." } \\
\text { Lower scores indicate: "a tradition of depending on physical force or illegal means to settle claims." Upon changes } \\
\text { in government new leaders "may be less likely to accept the obligations of the previous regime." }\end{array}$ \\
\hline $\begin{array}{l}\text { Corruption in } \\
\text { government }\end{array}$ & $\begin{array}{l}\text { Lower scores indicate "high government officials are likely to demand special payments" and that "illegal } \\
\text { payments are generally expected throughout lower levels of government" in the form of "bribes connected with } \\
\text { import and export licenses, exchange controls, tax assessment, police protection, or loans." }\end{array}$ \\
\hline
\end{tabular}

\section{Further results: Has the speed of convergence been uniform across the world?}

While on average institutions are converging worldwide, the average trends may still mask considerable variation in the experience of individual regions. In this section, we investigate this possibility. This is equivalent to testing if the process of conditional convergence is more pronounced in developing regions or in the transition economies, due to region-specific characteristics.

Dividing the sample into advanced, transition and into developing economies regions (according to their continents), we estimate a version of equation (2) augmented with interaction terms between initial level of institutions and transition, Latina America, MENA, 
Asia and sub-Saharan Africa dummies (advanced economies being the benchmark). Table 3 presents the results. Surprisingly, the discernible regularity is that there is no evidence of stronger (conditional) convergence in the group of transition economies. There seems to be some evidence that there has been stronger convergence in Latin America, Asia, sub-Saharan Africa and the MENA region. However, the trends are not consistent across measures and, apart from one case, an F-test finds no evidence of significantly different regional effects.

\begin{tabular}{|c|c|c|c|c|c|}
\hline 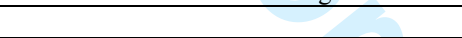 & Fraser Institute & leasures & \multicolumn{3}{|l|}{ ICRG measures } \\
\hline & $\begin{array}{l}\text { Legal system } \\
\text { and property } \\
\text { rights, 1985- } \\
2010\end{array}$ & $\begin{array}{l}\text { Legal system } \\
\text { and property } \\
\text { rights, 1980- } \\
2010\end{array}$ & $\begin{array}{l}\text { Bureaucratic } \\
\text { quality, 1985- } \\
2010\end{array}$ & $\begin{array}{l}\text { Rule of law, } \\
1985-2010\end{array}$ & $\begin{array}{l}\text { Corruption in } \\
\text { government, } \\
1985-2010\end{array}$ \\
\hline Initial value & $\begin{array}{l}-0.003^{*} \\
(0.002)\end{array}$ & $\begin{array}{l}-0.003^{*} \\
(0.002)\end{array}$ & $\begin{array}{l}-0.007 * * * \\
(0.002)\end{array}$ & $\begin{array}{l}-0.006 * * * \\
(0.002)\end{array}$ & $\begin{array}{l}-0.002 \\
(0.002)\end{array}$ \\
\hline Initial value * Latin America dummy & $\begin{array}{l}-0.007 * * * \\
(0.003)\end{array}$ & $\begin{array}{l}-0.004 * \\
(0.002)\end{array}$ & $\begin{array}{l}-0.005^{*} \\
(0.003)\end{array}$ & $\begin{array}{l}-0.004 \\
(0.003)\end{array}$ & $\begin{array}{l}-0.005^{*} \\
(0.003)\end{array}$ \\
\hline Initial value * Asia dummy & $\begin{array}{l}-0.002 \\
(0.003)\end{array}$ & $\begin{array}{l}-0.001 \\
(0.002)\end{array}$ & $\begin{array}{l}-0.005^{* *} \\
(0.002)\end{array}$ & $\begin{array}{l}-0.003 \\
(0.002)\end{array}$ & $\begin{array}{l}-0.009^{* *} \\
(0.004)\end{array}$ \\
\hline Initial value * sub-Sah. Africa dummy & $\begin{array}{l}-0.005^{*} \\
(0.003)\end{array}$ & $\begin{array}{l}-0.003 \\
(0.002)\end{array}$ & $\begin{array}{l}-0.004 \\
(0.004)\end{array}$ & $\begin{array}{l}-0.004 * * \\
(0.002)\end{array}$ & $\begin{array}{l}-0.009^{* * *} \\
(0.003)\end{array}$ \\
\hline Initial value $*$ MENA dummy & $\begin{array}{l}-0.007 * * \\
(0.003)\end{array}$ & $\begin{array}{l}-0.007 * * * \\
(0.002)\end{array}$ & $\begin{array}{l}-0.002 \\
(0.002)\end{array}$ & $\begin{array}{l}-0.001 \\
(0.004)\end{array}$ & $\begin{array}{l}-0.005 \\
(0.004)\end{array}$ \\
\hline Initial value * Transition econ. dummy & $\begin{array}{l}-0.003 \\
(0.003)\end{array}$ & & $\begin{array}{l}-0.003 \\
(0.003)\end{array}$ & $\begin{array}{l}-0.003 \\
(0.003)\end{array}$ & $\begin{array}{l}-0.003 * \\
(0.002)\end{array}$ \\
\hline Constant & $\begin{array}{l}-0.031 \\
(0.022)\end{array}$ & $\begin{array}{l}-0.002 \\
(0.022)\end{array}$ & $\begin{array}{l}0.012 \\
(0.036)\end{array}$ & $\begin{array}{l}0.005 \\
(0.027)\end{array}$ & $\begin{array}{l}-0.037 \\
(0.054)\end{array}$ \\
\hline F-stat & $10.565 * * *$ & $27.058 * * *$ & $17.820 * * *$ & $131.930^{* * *}$ & $13.760^{* * *}$ \\
\hline Adj. R-Squared & 0.609 & 0.732 & 0.590 & 0.602 & 0.551 \\
\hline Obs. & 92 & 78 & 95 & 95 & 95 \\
\hline RMSE & 0.008 & 0.006 & 0.019 & 0.014 & 0.014 \\
\hline$\beta_{\text {LATIN AMERICA }}$ & $-0.011 * * *$ & $-0.007 * * *$ & $-0.011 * * *$ & $-0.010 * * *$ & $-0.007 * * *$ \\
\hline$\beta_{\mathrm{ASIA}}$ & $-0.006 * * *$ & $-0.004 * * *$ & $-0.011 * * *$ & $-0.008 * * *$ & $-0.010^{* * *}$ \\
\hline$\beta_{\text {SUB-SAHARAN AFRICA }}$ & $-0.008 * * *$ & $-0.006 * * *$ & $-0.011 * * *$ & $-0.010 * * *$ & $-0.010 * * *$ \\
\hline$\beta_{\text {MENA }}$ & $-0.011 * * *$ & $-0.010 * * *$ & $-0.008 * * *$ & $-0.007 * *$ & $-0.006^{*}$ \\
\hline$\beta_{\text {TRANSITION }}$ & $-0.006 * * *$ & & $-0.009 * * *$ & $-0.008 * *$ & -0.004 \\
\hline$H_{0}:$ Binteraction terms are equal ( $p$-value) & 0.118 & 0.009 & 0.400 & 0.884 & 0.166 \\
\hline \multicolumn{6}{|c|}{$\begin{array}{l}\text { Notes: the dependent variable is the average annual growth rate of each institutional measure. Symbols } *, * * \text { and } * * * \text { stand for } \\
\text { significant at } 10,5 \text { and } 1 \% \text { respectively, two-tailed test. Heteroskedasticity-Robust Standard errors are in parentheses. Each conditional } \\
\text { convergence regression controls for the initial value of: per capita GDP (natural log), secondary enrolment rate, Polity } 2 \text { index, regional } \\
\text { dummies (Latin America, Asia, Sub-Saharan Africa, Middle East and North Africa and transition economies), legal origins dummies } \\
\text { (French, German, Scandinavian and Socialist systems), latitude, ethnic fractionalisation and share of major religions (Catholic, Muslim } \\
\text { and other major religions). }\end{array}$} \\
\hline
\end{tabular}

\section{Further robustness checks: are the results driven by the functional form?}

Since there is no established theory suggesting a functional for regressions on convergence in institutions, it would be reassuring to report a series of test results based on an alternative functional form. The simplest alternative test for convergence in institutions is to regress the observed changes over time on a given measure on the measure's initial values 
across countries. Let $G_{i t}$ denote the observed index (any measure) in country $i$ observed at both date $t=0$ and $t=D$. A test equation for (unconditional) convergence is then:

$$
\mathrm{G}_{t D}-\mathrm{G}_{t 0}=\alpha+\beta \mathrm{G}_{t 0}+\varepsilon_{i} \quad \text { with } i=1, \ldots, N
$$

where $\alpha$ and $\beta$ are parameters to be estimated and $\varepsilon_{i}$ is a zero mean error term. According to (A1), a negative (positive) estimate of the parameter $\beta$ implies that there is institutional convergence (divergence). Table A4 replicates the key results of the paper (table 2), showing that they are insensitive to changing the functional form.

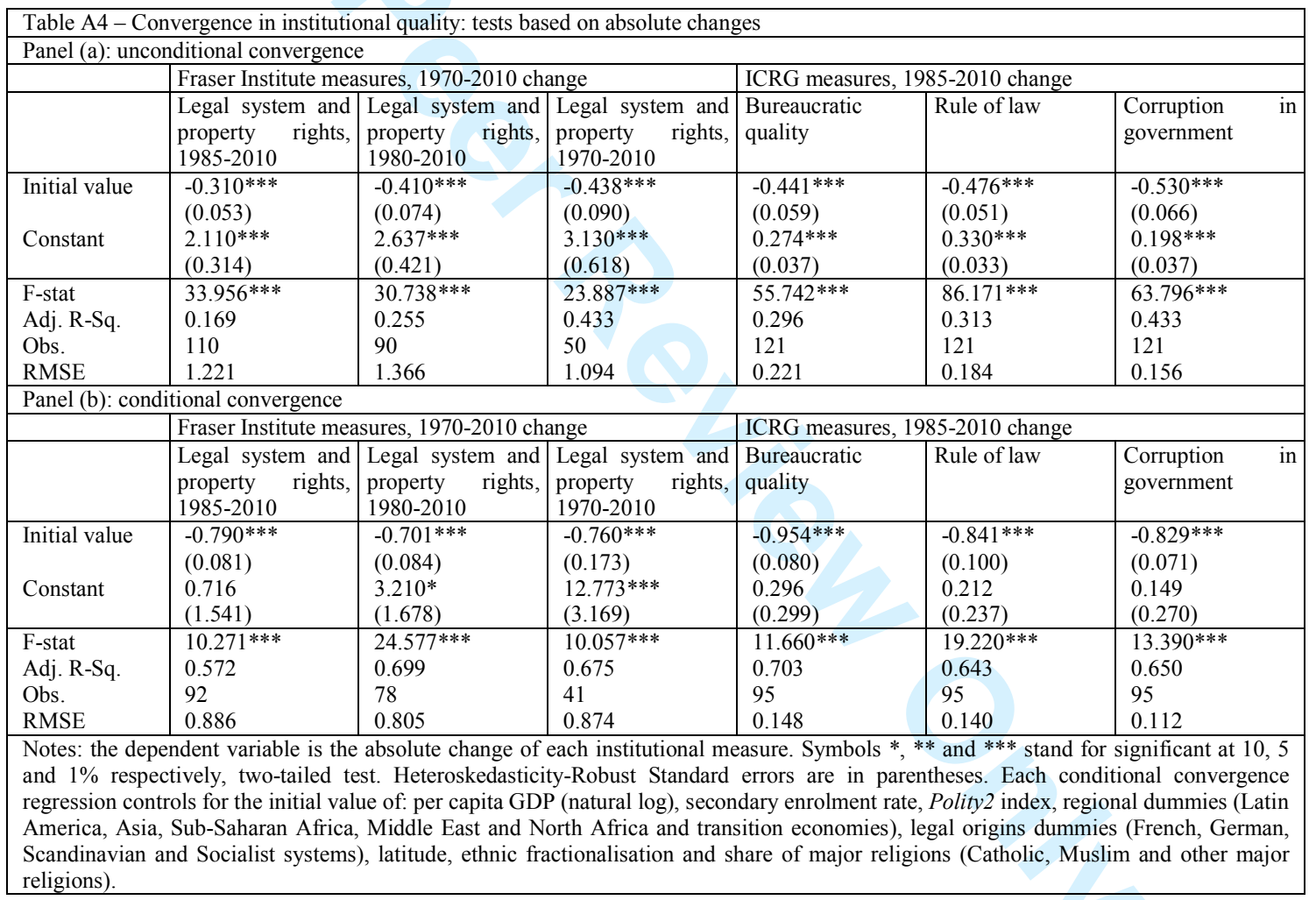

\section{Further robustness checks: do influential or outlying observations drive the results?}

The results are generally insensitive to using robust regression methods and to formal checks for influential and outlying observations. First, we estimate each of the above regressions using Iteratively Reweighted Least Squares (IRLS), which down-weights 
observations with large residuals. The results show little divergence from those presented above. Similarly, by excluding from the regression countries with large DFITS statistics (the threshold is $\mid$ DFITS $_{j} \mid>2 \sqrt{k / N}$ ), we conclude that influential observations do not significantly affect our estimates. In addition, we have calculated DFBETA statistics to check whether influential observations affect the magnitude of the convergence parameter, $\beta$. Its estimate shows little sensitivity once we remove from the regressions values that are above the cut-off $\left|D F B E T A_{j}\right|>2 \sqrt{N}$. For example, countries that seem to be potentially influential for the convergence parameter of the Quality of Legal System and Security of Property Rights index are Venezuela, Central African Republic, Peru and Guatemala. Finally, we rerun the convergence regressions once we exclude the observations with the highest levels of initial institutional quality, removing from the original sample the top decile of countries with the highest initial level of institutional quality (or even all the advanced economies, in an alternative version). For both types of checks, the coefficient of the initial value remains negative, highly significant and stable at the conventional levels for all measures. In sum, this exercise provides evidence in support of the generality of the results. 


\section{Notes on revisions for FJDS-2013-Aug-0088-R2}

"Do we see convergence in institutions? A cross-country analysis"

Here we outline the revisions undertaken in response to Refereel's report. Once again, we must thank this colleague for his/her time and dedication. The paper has greatly benefited from the comments.

\section{Referee: 1}

"The authors have made an effort to more seriously address my comments this time. I have two comments left.

1. The authors have performed robustness checks to take my main concerns into account. It seems that the reported results lend some credence to those concerns, and therefore qualify the claims that the authors make in their paper.

However, the authors only report the results in their report to the referees and simply mention them in passing in the manuscript.

Because the new results bring important qualifications, Tables R2.1 and R2.2 should be reported and commented in the body of their paper."

Response:

We agree with the Referee. It is useful to report both abovementioned additional results.

In particular, we report and comment on Table R2.2 (on quantile regressions) in the paper: significantly restructuring section 4.3 (part of which has been moved to the online appendix). Instead, we are compelled to report and comment on Table R2.1 in the online appendix (endnote vi, in the body of the paper, refers the interested reader to it). This is dictated by the fact that the editor has set a strict wordcount of 9,000 words, with as few tables as feasible, and it would have not been possible to incorporate such table in the paper without significantly exceeding such limit.

"2. A secondary remark deals with the question of endogeneity. I agree that observing a negative coefficient on the initial value of an institutional quality index signals that institutional quality "has converged" over the period of study. However, if the observed convergence was driven by a period-specific phenomenon, like globalization or the end of the Cold war, then one cannot claim that institutional quality "converges", because there is no general mechanism driving convergence.

This point is backed by the review of the literature. It enumerates reasons why institutional quality may have converged, but no systematic mechanism linking the variation of institutions to their level, which would be the analogue of the convergence mechanism in the Solow growth model.

Using the past tense to signal the observed phenomenon's likely historicity, or lack of generality, is therefore more than a semantic stylishness. It is necessary to correctly interpret the results without overselling them."

Response: 
Point well taken. Since there is no systematic mechanism indicating that institutional quality should converge, the correct interpretation of the evidence presented is only that we observed (slow) convergence over the period of study.

To address this comment, we have rephrased the interpretation of the convergence tests throughout the paper using the past tense (or present perfect). In particular, we have made four such changes in section 5 , two in section 4.6 , three in section 4.2 , and five in section 1 . 